\title{
Momentum profits and time-varying unsystematic risk
}

Article

Accepted Version

Li, X., Miffre, J., Brooks, C. and O'Sullivan, N. (2008)

Momentum profits and time-varying unsystematic risk. Journal of Banking \& Finance, 32 (4). pp. 541-558. ISSN 0378-4266 doi: https://doi.org/10.1016/j.jbankfin.2007.03.014 Available at https://centaur.reading.ac.uk/18681/

It is advisable to refer to the publisher's version if you intend to cite from the work. See Guidance on citing.

To link to this article DOI: http://dx.doi.org/10.1016/j.jbankfin.2007.03.014

Publisher: Elsevier

All outputs in CentAUR are protected by Intellectual Property Rights law, including copyright law. Copyright and IPR is retained by the creators or other copyright holders. Terms and conditions for use of this material are defined in the End User Agreement.

\section{www.reading.ac.uk/centaur}

\section{CentAUR}

Central Archive at the University of Reading

Reading's research outputs online 
NOTICE: this is the author's version of a work that was accepted for publication in the Journal of Banking and Finance. Changes resulting from the publishing process, such as peer review, editing, corrections, structural formatting, and other quality control mechanisms may not be reflected in this document. Changes may have been made to this work since it was submitted for publication. A definitive version was subsequently published in the Journal of Banking and Finance, 32.4 (2008), DOI: 10.1016/j.jbankfin.2007.03.014 


\title{
Momentum Profits and Time-Varying Unsystematic Risk ${ }^{\bullet}$
}

\author{
Xiafei Li*, Joëlle Miffre**, Chris Brooks***, and Niall O'Sullivan****
}

\begin{abstract}
This study assesses whether the widely documented momentum profits can be attributed to time-varying risk as described by a GJR-GARCH(1,1)-M model. We reveal that momentum profits are a compensation for time-varying unsystematic risks, which are common to the winner and loser stocks but affect the former more than the latter. In addition, we find that, perhaps because losers have a higher propensity than winners to disclose bad news, negative return shocks increase their volatility more than it increases those of the winners. The volatility of the losers is also found to respond to news more slowly, but eventually to a greater extent, than that of the winners.
\end{abstract}

Keywords: Momentum profits, Unsystematic risk, GJR-GARCH(1,1)-M model JEL classifications: G12, G14

This version: 29 March 2007

* Cass Business School, City University (UK),

** EDHEC (France),

*** ICMA Centre, University of Reading (UK),

**** Department of Economics, University College Cork (Ireland).

Author for correspondence: Chris Brooks, ICMA Centre, University of Reading, Whiteknights, PO Box 242, Reading, RG6 6BA, UK; tel: (+44) 118378 7809; fax: (+44) 118931 4741; e-mail: $\underline{\text { C.Brooks@ rdg.ac.uk }}$

- The authors would like to thank two anonymous referees for useful comments on a previous version of this paper. The usual disclaimer applies. 


\section{Introduction}

Momentum strategies that buy recent winners and sell recent losers are profitable over short horizons of 3 to 12 months (Jegadeesh and Titman, 1993). Price continuation has prevailed over time (Jegadeesh and Titman, 2001), across countries (Griffin et al., 2003; Liu et al., 1999; Ellis and Thomas, 2003), across industries (Moskowitz and Grinblatt, 1999), across equity styles (Chen and De Bondt, 2004) and across asset classes (Okunev and White, 2003). While the profitability of relative-strength portfolios is not disputed, there is still a lot of controversy as to why these abnormal returns occur. Two explanations have been put forward.

The first is based on psychology and market inefficiency. Behavioral proponents relate price under- and over-reaction to cognitive errors that investors make when incorporating information into prices. For example, investors may be too quick to draw the conclusion that a given stock follows a particular "ideal type" (the representativeness heuristic), and they may be too slow to update their beliefs when confronted with new, especially contradictory, evidence (the conservatism bias). These behavioral attributes lead first to momentum as stock prices react with delay to firmspecific information and, once deviations from equilibrium are acknowledged, to subsequent mean reversion (Barberis et al., 1998; Daniel et al., 1998; Hong and Stein, 1999). ${ }^{1}$ This suggests that the irrationality from which agents suffer may push prices away from fundamentals and allow profitable mispricings to survive.

The second explanation relies on the notion of market efficiency and argues that the returns of the relative-strength portfolios are a fair compensation for the risk and/or trading costs of implementing the strategies. On balance, however, the evidence suggests that the profitability of the relative-strength portfolios is not solely a compensation for exposure to higher risks (Jegadeesh and Titman, 1993; Chan et al., 1996; Fama and French, 1996; Griffin et al., 2003; Karolyi and Kho, 2004; Sadka, 2006). ${ }^{2}$ Studies that allow for time-variation in systematic risks reach conflicting

\footnotetext{
${ }^{1}$ Other behavioral deficiencies that investors may suffer from include biased self-attribution and overconfidence (Daniel et al., 1998), and bounded rationality (Hong and Stein, 1999).

2 Jegadeesh and Titman (1993) estimate a market model, to which Chan et al. (1996) and Fama and French (1996) add the return of portfolios sorted on size and book-to-market value. Griffin et al. (2003) look at macroeconomic and
} 
conclusions. While Chordia and Shivakumar (2002), Wu (2002) and Wang (2003) explain the profitability of momentum strategies through time-variation in expected returns, Grundy and Martin (2001), Griffin et al. (2003) and Nagel and Lewellen (2003) argue that the momentum returns are too large to be accounted for in terms of time-varying risks. It is important to note also that a rationale related to transaction costs has been put forward as an explanation for the momentum profits. Lesmond et al. (2004) indeed argue that momentum profits have little to do with risk as they are simply an illusion induced by trading costs. ${ }^{3}$

The contribution of this article to the momentum literature is with regards to the time-varying unsystematic risk of the winners and the losers and to the role it may have in explaining the abnormal returns of momentum strategies. While several studies look at variations in systematic risk (Grundy and Martin, 2001; Chordia and Shivakumar, 2002; Wu, 2002; Griffin et al., 2003; Wang, 2003; Nagel and Lewellen, 2006), this study is the first to look at variations in the unsystematic risks of the winner and loser portfolios. We do this within a GJR-GARCH(1,1)-M framework. ${ }^{4}$ The rationale for choosing a $\operatorname{GARCH}(1,1)-\mathrm{M}$ model stems from the idea that in rational markets, volatility is often viewed as being commensurate with news or information flow, and indeed, the autocorrelation in information arrival ("news evens happen in bunches") is one of the primary rationalizations of the volatility clustering that is almost universally observed in asset returns. The conditional standard deviation term in the mean equation captures the time-varying relationship between total risk and returns, and thus our contribution is to link momentum profits with the impact of news on returns. We use the GJR variant of the basic GARCH model in order to allow for a possible asymmetry in the relationship between the returns to the winner and loser portfolios and the volatility. By using a conditional model, we are able to capture the possibility that

\footnotetext{
financial factors that are in the spirit of the model of Chen et al. (1986). Sadka (2006) looks at the role of liquidity risk. Karolyi and Kho (2004) use bootstrap experiments and a wide range of return-generating processes.

${ }^{3}$ Lesmond et al. (2004) show that momentum strategies are highly trading intensive and pick up stocks that are expensive and risky (small, high beta, illiquid, off-NYSE extreme performers). Besides, the momentum profits are mainly driven by the losers (Hong et al., 2000) and thus short-sale costs also need to be taken into account.

${ }^{4}$ GJR-GARCH(1,1)-M stands for Glosten et al. (1993) Generalized Autoregressive Conditional Heteroscedasticity of order 1,1 with a Mean term that models the conditional risk premium. A number of studies (Nelson, 1991; Glosten et al., 1993; Rabemananjara and Zakoian, 1993) show that good news (measured by positive return shocks) and bad news (measured by negative return shocks) have an asymmetric impact on the conditional variance of stock returns.
} 
the risks of the winners and the losers may change in a predictable, but different, way over time. This suggests that a model that explicitly allows for risk to be time-dependent might explain the abnormal returns of the momentum strategies. Our approach is an alternative to one where prespecified conditional variables, such as macroeconomic or firm-specific influences, are used as the risk factors in a conditional pricing model. Most such models have largely failed to explain the profitability of relative strength portfolios, and thus an advantage of the method that we employ is that it does not require any a priori specification of the set of risk factors in order to allow for timevarying risk.

We draw the following two conclusions from our analysis. First, we identify some clear patterns in the volatility of the winner and loser portfolios. The volatility of the winners is found to be more sensitive to recent news than that of the losers, whereas by contrast, the volatility of the losers is found to be more sensitive to distant news than that of the winners. Besides, the volatility of the losers (with an average volatility half-life of 24 months and 13 days) shows a higher level of persistence than that of the winners (whose volatility half-life only equals 3 months and 5 days on average). The second conclusion is with regards to the hypothesis that the momentum returns are a compensation for time-varying unsystematic risk as modeled by the GJR-GARCH(1,1)-M model. We show that the GJR-GARCH(1,1)-M terms, when added to the traditional market and Fama and French models, explain the abnormal performance of the momentum strategies without the need to resort to the transactions cost and illiquidity issues that were the focus of Lesmond et al. (2004) or Sadka (2006). Interestingly, neither the GJR-GARCH(1,1) nor the GARCH(1,1)-M specifications alone could account for the abnormal return of the relative-strength portfolios. It is therefore both the asymmetric response of the losers to good and bad news and the conditional risk premium embedded in the GARCH(1,1)-M model that explain the profitability of the momentum strategies. We also observe a strong impact of old news for the losers, which we rationalize by arguing that when a firm with no or low analyst coverage receives bad news, its managers are likely to withhold that news as disclosing it would put downward pressure on price. Since losers are more likely than winners to sit on bad news, they are also more likely to withhold information. 
The remainder of the paper is organized as follows. Section 2 introduces the dataset, the methodology employed to construct the momentum portfolios and the models used to adjust for risk. Section 3 analyzes how recent news, distant news and negative return shocks impact the volatility of the winners and losers. It also tests whether the momentum profits are a compensation for timevarying unsystematic risk common to the winners and losers. Finally, section 4 concludes the paper with a summary of our findings.

\section{Data and Methodology}

Monthly UK stock prices adjusted for dividends are obtained from the London Share Price Database over the period 28 February 1975 to 31 December $2001 .^{5}$ To address problems of survivorship bias, we also include stocks that were delisted due to merger, acquisition or bankruptcy. The sample includes all companies with at least 3 months of available returns. A total of 6,155 companies are considered.

All stocks are ranked and sorted into 10 equally-weighted portfolios based on their past $J$-month cumulative returns $(J=3,6,12$ months). The decile portfolio with the highest cumulative return is termed the "winner" portfolio, while the decile portfolio with the lowest cumulative return is called the "loser" portfolio. The return on the momentum portfolio is then measured as the return difference between the winner and loser portfolios over the next $K$ months ( $K=3,6,12$ months). ${ }^{6}$ The resulting portfolio is referred to as the $J-K$ momentum portfolio. The procedure is rolled forward at the end of each holding period to produce new winner, loser and momentum portfolios. The formation of the relative-strength portfolios is therefore non-overlapping, thus reducing the trading frequency and the transaction costs incurred in portfolio construction and ensuring that statistical tests are valid without requiring modification of the standard errors. Our framework is also more realistic in terms of the behavior of investors than one based on overlapping portfolios where they would presumably have to vary the amount of wealth devoted to the strategies over time.

\footnotetext{
${ }^{5}$ The returns to the Fama-French factor portfolios that we employ subsequently are only available to December 2001, which necessitates this truncation of our sample period.

${ }^{6}$ We also employed holding periods of 15 months' duration, but the results were qualitatively identical to those employing a 12-month horizon and are therefore not reported.
} 
Traditionally, performance has been measured by regressing a portfolio's returns on a set of systematic risk factors emanating from the CAPM of Sharpe (1964) or the three-factor model of Fama and French (1993), which can be expressed respectively as

$$
\begin{aligned}
& R_{t}=\alpha+\beta\left(R_{M t}-R_{f t}\right)+\varepsilon_{t} \\
& R_{t}=\alpha+\beta\left(R_{M t}-R_{f t}\right)+s S M B_{t}+h H M L_{t}+\varepsilon_{t}
\end{aligned}
$$

where $R_{t}$ is either the return on the momentum portfolio or the return of the winner and loser portfolios in excess of the risk-free rate, $R_{f t}$ is the three-month Treasury bill rate, $R_{M t}$ is the valueweighted market return on all stocks quoted on the London Stock Exchange, $S M B_{t}$ and $H M L_{t}$ are UK-based returns of Fama and French (1993) size and book-to-market value portfolios as provided by $\mathrm{Nagel}^{7}$ and $\varepsilon_{t}$ is a white noise error term. The performance of the portfolios is then evaluated by testing the statistical significance of the $\alpha$ coefficient in (1) and (2). The Carhart (1997) four-factor version of the Fama-French model is often used in performance attribution for mutual funds. The fourth factor, known as UMD ("up-minus-down") is a measure of the return to momentum portfolios. The key distinction between this approach and what we propose here is that we are trying to explain the profitability of momentum portfolios using a previously unexamined measure of risk, whereas the UMD term uses momentum to explain the returns from other strategies. Thus, in our study, momentum is the explained variable whereas in the Carhart model, it is an explanatory variable.

Embedded in equations (1) and (2) is the assumption that $\varepsilon_{t} \sim N\left(0, \sigma^{2}\right)$ and, thus, that there is no conditional volatility in the market. Since Engle (1982), numerous studies have been written on the family of GARCH models (Poon and Granger, 2003; Andersen et al., 2006; Bauwens et al., 2006). The attractiveness of the GARCH models stems from the fact that they model the conditional variance of asset returns by taking into account persistence in volatility (where volatility shocks today influence expected volatility many months from now) and "leverage effects" (where negative return shocks impact volatility more than positive return shocks of the same magnitude). These two

\footnotetext{
${ }^{7}$ These data are available at http://faculty-gsb.stanford.edu/nagel/data/UK_FFFact.csv
} 
features are central to our hypotheses that the losers' volatilities show more persistence and asymmetry than those of the winners.

We investigate whether momentum profits in the UK are a compensation for time-varying risk within GJR-GARCH(1,1)-M versions of the market and Fama and French models:

$$
\begin{aligned}
& R_{i, t}=\alpha_{i}+\beta_{i}\left(R_{M t}-R_{f t}\right)+\delta_{i} \sigma_{i, t}+\varepsilon_{i, t} \\
& \sigma_{i, t}^{2}=\omega_{i}+\gamma_{i} \varepsilon_{i, t-1}^{2}+\eta_{i} I_{i, t-1} \varepsilon_{i, t-1}^{2}+\theta_{i} \sigma_{i, t-1}^{2} \\
& R_{i, t}=\alpha_{i}+\beta_{i}\left(R_{M t}-R_{f t}\right)+s_{i} S M B_{t}+h_{i} H M L_{t}+\delta_{i} \sigma_{i, t}+\varepsilon_{i, t} \\
& \sigma_{i, t}^{2}=\omega_{i}+\gamma_{i} \varepsilon_{i, t-1}^{2}+\eta_{i} I_{i, t-1} \varepsilon_{i, t-1}^{2}+\theta_{i} \sigma_{i, t-1}^{2}
\end{aligned}
$$

Where, for portfolio $i\left(i=\right.$ winner, loser or momentum), $\sigma_{i, t}^{2}$ is the conditional variance of the winner, loser and momentum portfolios, $\delta_{i} \sigma_{i, t}$ measures the time-varying risk premium, $\gamma_{i} . \eta_{i}$ relates to the lagged squared error term and measures the impact of recent news on volatility, $\eta_{i}$ also measures any asymmetric response of volatility to bad and good news (commonly attributed to as leverage effect), $I_{i, t-1}=1$ if $\varepsilon_{i, t-1}<0$ (bad news, also called negative return shock) and $I_{i, t-1}=0$ otherwise, $\theta_{i}$ relates to the lagged conditional volatility and measures the impact of old news on volatility.

Within the framework of systems (3) and (4), the following two hypotheses can be tested. First, the coefficients on conditional volatility indicate how news impacts the volatility of the winners and of the losers. In particular, we analyze the speed of the response of the winners and losers to news and test for the presence of any asymmetry in the response of the winners' and losers' volatilities to good and bad news. Second, the sign and significance of $\alpha$ in the mean equations of systems (3) and (4) indicate whether the momentum returns are a compensation for market risk, the risks associated with size and book-to-market value and time-varying, unsystematic risk. We also test whether the momentum profits can be explained by a simplified version of the above models in the standard GARCH(1,1)-M framework. This specification models the timevarying risk premium as in (3) and (4) but does not allow for asymmetric response of volatility to good and bad news. Practically, this breaks down to estimating the following systems of equations 
$R_{t}=\alpha+\beta\left(R_{M t}-R_{f t}\right)+\delta \sigma_{t}+\varepsilon_{t}$

$\sigma_{t}^{2}=\omega+\gamma \varepsilon_{t-1}^{2}+\theta \sigma_{t-1}^{2}$

$R_{t}=\alpha+\beta\left(R_{M t}-R_{f t}\right)+s S M B_{t}+h H M L_{t}+\delta \sigma_{t}+\varepsilon_{t}$

$\sigma_{t}^{2}=\omega+\gamma \varepsilon_{t-1}^{2}+\theta \sigma_{t-1}^{2}$

\section{Empirical Results}

Table 1 presents summary statistics for the winner, loser and momentum portfolios. The rows represent the ranking periods ( $J=3,6$ and 12 months) and the columns represent the holding periods ( $K=3,6$ and 12 months). It is clear from this table that the winners systematically outperform the losers at the $1 \%$ level. Across strategies, the momentum portfolios earn an average return of 0.0151 a month, with a range from 0.0093 for the $3-3$ strategy to 0.0193 for the 6-6 strategy. ${ }^{8}$ These results corroborate those of Liu et al. (1999) and Ellis and Thomas (2003) for the UK. Table 1 also reports the monthly standard deviations and reward-to-risk ratios of each portfolio returns. Consistent with rational expectations, the momentum portfolios with higher returns have also more risk. For instance, the 6-6 strategy earns the highest average return $(0.0193)$ and, with a standard deviation of 0.0511 , it is also the second most volatile strategy. With a rewardto-risk ratio of 0.3856 , the 12-6 strategy generates the highest average return in risk-adjusted terms, while the 3-3 strategy offers the lowest risk-adjusted return $(0.1925)$.

The contribution of the article is with regards to the time-varying unsystematic risk of the winner and loser portfolios and the impact that it may have on momentum profits. With this in mind, we first analyze the performance of the winner, loser and momentum portfolios within the standard market and Fama and French models and then allow for time-varying unsystematic risk through different specifications of the $\operatorname{GARCH}(1,1)$ model. While doing this, we will also analyze the impact of recent news, old news and bad news on the volatility of the winners and losers.

\footnotetext{
${ }^{8}$ Note that all figures in this study refer to monthly proportion returns rather than percentage returns, unless otherwise stated.
} 


\section{1. Static market and Fama and French models}

Table 2 reports the OLS estimates of the market and Fama and French models (1) and (2) for the winner, loser and momentum portfolios. ${ }^{9}$ In line with previous research (Jegadeesh and Titman, 1993; Fama and French, 1996; Karolyi and Kho, 2004), the results indicate that traditional versions of the market and Fama and French models fail to explain momentum profits. Regardless of the model, of the ranking period, and of the holding period, the $\alpha$ coefficients of the momentum strategies in equations (1) and (2) are positive and significant at the $1 \%$ level. The momentum profits estimated from the market model range from 0.0095 (3-3 strategy) to 0.0194 (6-6 strategy), with an average return at 0.0151 a month. According to the Fama and French model, the winners outperform the losers by 0.0177 on average, with a range of 0.0110 (3-3 strategy) to 0.0222 (12-6 strategy). While systematic risk explains most of the over-performance of the winners, it fails to account for the under-performance of the losers. Irrespective of the ranking period, of the holding period and of the risk model considered, the losers indeed have negative alphas that are significant at the $1 \%$ level. As in Hong et al. (2000), the momentum profits are therefore driven by the losers.

The factor loadings on $R_{M t}, S M B_{t}$ and $H M L_{t}$ in (1) and (2) suggest that the winner and loser portfolios tend to pick small capitalization stocks $(s>0)$ with high market risk $(\beta>0)$. The winners have growth characteristics $(h<0)$ and the losers have value characteristics $(h>0)$. The momentum strategies are predominantly market-neutral $(\beta=0)$ and size-neutral $(s=0)$ and have negative loadings on $H M L_{t}$. These results are consistent with those previously reported, including the studies by Chan et al. (1996) and Liu et al. (1999).

\section{2. GARCH(1,1) versions of market and Fama and French models}

Table 3 reports estimates of the market and Fama and French models (3) and (4) that include a GJR-GARCH(1,1)-M term. To facilitate exposition, the averages across ranking and holding periods of the coefficient estimates are discussed in the following section for the winner, loser and momentum portfolios, but are not reported directly in the Table due to space constraints. The

\footnotetext{
${ }^{9}$ Engle (1982)'s ARCH-LM test provides strong evidence of heteroscedasticity in the OLS residuals of the market and Fama-French models. Hence, we use White's heteroscedasticity-robust standard errors.
} 
estimation method is Maximum Likelihood with Bollerslev-Wooldridge robust standard errors. We first analyze how news, whether it is recent, distant or negative, impacts the volatility of the winners and the losers. We subsequently test for whether the time-varying unsystematic risk common to the winners and losers explains the profitability of the momentum strategies.

\section{The pattern of conditional volatility}

The coefficients $\gamma$ and $\eta$ in systems (3) and (4) relate to the lagged squared error term and, therefore, to the impact of recent news on volatility. The average $\gamma+\eta / 2$ of the conditional market model equals 0.2554 for the winners and 0.1262 for the losers. While the parameters in the conditional variance equation of a symmetric GARCH model are usually required to be positive, when the GJR form of the model is used, it is possible for the parameter on the asymmetry term ( $\eta$ in our notation) to be negative. More specifically, if $\mathrm{E}\left(\mathrm{I}_{\mathrm{t}}\right)=1 / 2$, then provided that $\gamma>\eta / 2$, the negative parameter would not lead the conditional variance to be negative. We have checked this condition and it is satisfied for all models estimated in this study. The average $\gamma+\eta / 2$ of the conditional Fama and French model is 0.2867 for the winners and 0.1551 for the losers. Clearly, recent news impacts the volatility of the winners more than it impacts that of the losers. With only one exception (the 3-3 winner in the Fama and French model), the conclusion holds throughout in Table 3, irrespective of the ranking period, of the holding period and of the model considered.

The coefficient $\theta$ in systems (3) and (4) reflects the effect of lagged conditional variance and captures the impact of "old news" on volatility. The results of the conditional market model in Table 4 indicate that the average $\theta$ coefficient of the winners $(0.5785)$ is lower than that of the losers (0.7911). The same conclusion applies to the conditional Fama and French model, for which the winners have an average $\theta$ coefficient of 0.5017 and the losers an average $\theta$ coefficient of 0.8072. It is clear therefore that "old news" has more impact on the volatility of the losers than on the volatility of the winners. Looking at the estimates of $\theta$ in Table 3, it appears that the conclusion holds for the vast majority of the portfolios, the 12-12 winner in the market model being the only exception. 
The asymmetric coefficients $(\eta)$ in Table 3 suggest that bad news has different impacts on the volatility of the winners and on the volatility of the losers. For the losers, the mean of the $\eta$ coefficients is 0.3028 for the conditional market model and 0.2203 for the conditional Fama and French model. With only a few exceptions, these coefficients are significant at the $5 \%$ level in Table 3. Clearly, therefore, bad news increases the volatility of the losers. For the winner portfolios, however, the average $\eta$ coefficient equals -0.1852 for the conditional market model and 0.0949 for the conditional Fama and French model, with 14 out of 18 coefficients that are insignificant at the $5 \%$ level in Table 3. It follows that the announcement of bad news does not have any noticeable impact on the volatility of the winners. It may be the case that stocks whose recent performance has already been poor are hit much harder by further bad news than stocks recently performing well, which are able to absorb bad news more easily.

The evidence of Table 3 thus far indicates that, with relatively few exceptions, the losers have higher $\eta$ and $\theta$, and lower $\gamma$, than the winners. Table 3 also reports the persistence in volatility of the winners and losers, measured as $\gamma+\eta / 2+\theta$. The volatility of the losers appears to be more persistent than that of the winners. Indeed, the average $\gamma+\eta / 2+\theta$ of the losers (winners) equals $0.9172(0.8339)$ for the conditional market model and $0.9623(0.7885)$ for the conditional Fama and French model. For the conditional market model, this converts into volatility half-lives of 3 months and 18 days for the winners and 8 months for the losers. The volatility half-lives estimated from the conditional Fama and French model equal 2 months and 20 days for the winners and 18 months for the losers. Clearly and with only one exception out of 18 regressions, ${ }^{10}$ the volatility persistence of the losers exceeds that of the winners.

\section{The impact of time-varying firm specific risk on momentum profits}

Table 3 also reports, through $\delta$, the impact of conditional volatility on the returns of the winners, losers and momentum portfolios. An increase in conditional volatility decreases the return

\footnotetext{
${ }^{10}$ The exception is for the 12-12 winner in the conditional market model (Table 3).
} 
of both the winners and the losers, but increases the momentum returns. The $\delta$ coefficients of the momentum portfolios from the conditional market model range from 0.2718 (12-6 strategy) to 0.7616 (6-3 strategy) (Table 3) with an average at 0.4340. 6 (9) coefficients out of 9 are significant at the 5\% (10\%) level. Similar results are reported for the conditional Fama and French model, for which $\delta$ equals 0.4368 on average, with 6 (8) coefficients out of 9 that are significant and positive at the 5\% (10\%) level. This suggests that there is a positive relationship between time-varying risk and momentum return: A $1 \%$ increase in conditional volatility leads, on average, to a $0.43 \%$ increase in monthly momentum returns.

The factor loadings on $R_{M t}, S M B_{t}$ and $H M L_{t}$ for the conditional volatility model in Table 3 indicate that the winners and the losers have value characteristics $(h>0)$ and are tilted towards small-capitalization stocks $(s>0)$ with high market risk $(\beta>0)$. The latter two characteristics appear to corroborate the evidence from the unconditional Fama and French model (Table 2). As the loadings of the losers on $R_{M t}, S M B_{t}$ and $H M L_{t}$ are typically higher than those of the winners, the momentum portfolios have coefficients on the three Fama and French factors that are predominantly negative.

The main contribution of this paper is to test whether the momentum profits are a compensation for time-varying unsystematic risk as described by the GJR-GARCH(1,1)-M model. If this is indeed the case, then the $\alpha$ coefficients of the momentum strategies should be statistically indistinguishable from zero when these terms are incorporated into the risk attribution model. This conjecture is supported uniformly at the $5 \%$ level for both the conditional market and Fama and French models. The GJR-GARCH(1,1)-M market model is able to explain the momentum returns, since the alpha estimates are reduced both in magnitude and in statistical significance. The alphas indeed range from -0.0103 (12-3 strategy) to 0.0093 (12-6 strategy), with a mean at -0.0016 . The GJR-GARCH(1,1)-M Fama and French model does a good job of explaining the momentum profits too, with an average alpha of 0.0004 and a range of -0.0085 (12-3 strategy) to 0.0093 (6-6 strategy). Clearly, the results of Tables 2 and 3 suggest that adding a GJR-GARCH(1,1)-M structure to the 
models traditionally used to measure performance is crucial to explaining the abnormal return of momentum strategies. Interestingly, the considerable reduction in relative price strength returns after allowing for time-varying risk seems to stem from an increase in the performance of the loser portfolios. This suggests that the underperformance of the losers identified in Table 2 is in part due to their sluggish and asymmetric reaction to bad news.

\section{Analysis of results}

Proponents of the efficient markets hypothesis could argue that our results are an indication of momentum profits being merely a compensation for unsystematic risks common to the winners and losers but stronger for the former than the latter. This line of thought would therefore conclude that our findings are consistent with rational pricing in efficient markets. Thus, future research could seek to determine why unsystematic risk is important. It may be the case, for example, that the time-varying risks are related to industry effects, where certain industries that may be overrepresented in the momentum portfolios become relatively more or less risky in a cyclical fashion over time as they go into and out of investment favour.

However, our results are also consistent with a behavioural explanation along the lines of Hong, Lim and Stein (2000), where information on the loser stocks takes longer to be fully reflected in prices. The strong impact of old news identified for the losers and the persistence in their volatility are in support of the statement of Hong et al. that "bad news travels slowly". When a firm with no or low analyst coverage receives bad news, its managers are likely to withhold that news as disclosing it would put downward pressure on price. Since losers are more likely than winners to sit on bad news, they are also more likely to withhold information. For the losers, this converts into higher volatility persistence (or higher volatility half-lives) and higher sensitivity of volatility to distant news. The results in Table 3 also give credence to the conjecture that, for winners, good news travels fast. Managers of no or low coverage firms have strong incentives to disclose good news the minute it arrives as this stimulates the share price. Since winners are, by definition, more likely than losers to receive good news, they are more eager to disclose information. This converts 
in our setting into a higher sensitivity of winners' volatility to recent news and less volatility persistence (or lower volatility half-lives).

We identify another interesting pattern in the volatility of the winner and losers. Relative to the volatility of the winners, the volatility of the losers clearly shows an asymmetric response to good and bad news: bad news substantially increases the volatility of the losers, while it does not impact that of the winners. This is in line with the prediction of the behavioural argument put forward above. Since, relative to winners, losers have a higher probability of disclosing bad news, negative return shocks increase their volatility more than they increase that of the winners. The asymmetric response of losers to negative returns shocks could be explained as follows. Relative to winners, the probability that losers disclose bad news is far greater. Thus the announcement of a bad piece of news does not alter the volatility of winners (as bad news is expected to be transitory only) while it pushes up that of losers. When losers do disclose bad news, investors interpret this as a sign that their beliefs were correct, leading them to sell the losers. As a result, their volatility increases and becomes more persistent.

A failure to explicitly model the asymmetric response of the losers and winners to bad news might therefore lead us to under-estimate the volatility of the losers, and consequently their performance, following a price drop or to over-estimate the volatility of the winners, and consequently their performance, following a price rise. This motivates the hypothesis that the momentum profits might, at least in part, be a compensation for an asymmetric response of winners and losers to negative return shocks.

\section{Robustness of the results to the specification of the GARCH(1,1) model}

In this section, we test whether the momentum profits can be explained by a simplified version of the conditional models. Table 4 reports the parameter estimates of systems (5) and (6) for the winner, loser and momentum portfolios. Table 4 therefore assumes that the return and 
conditional volatility of the momentum portfolios are better described by a GARCH(1,1)-M model. $^{11}$

The omission of the leverage effect in Table 4 does not alter the main conclusions of Table 3 with regards to the pattern of volatility for the winners and the losers. For example, Table 3 and 4 document that the volatility of the winners $(W)$ is more sensitive to recent news than the volatility of the losers $(L)$; namely, $\gamma_{W}>\gamma_{L}$. Similarly, the impact of old news on volatility in Tables 3 and 4 is stronger for the losers; namely, $\theta_{L}>\theta_{W}$. Finally, volatility in both tables is found to be more persistent for the losers; namely, $\gamma_{L}+\eta_{L} / 2+\theta_{L}>\gamma_{W}+\eta_{W} / 2+\theta_{W}$ in Table 3 and $\gamma_{L}+\theta_{L}>$ $\gamma_{W}+\theta_{W}$ in Table $4 .{ }^{12}$ As a result, the average volatility half-lives are much smaller for the winners than for the losers. Across GARCH specifications, ranking periods, and holding periods, the volatility half-life of the winners is 3 months and 5 days on average, while that of the losers is 24 months and 13 days.

The omission of the leverage effect however has a direct impact on the significance of the time-varying risk parameter $\delta$ in Table 4 . Out of the $18 \delta$ coefficients estimated for the momentum strategies in Table 3,17 were significant at the $10 \%$ level. When, as in Table 4, the impact of news on volatility is assumed to be symmetric, the number of significant $\delta$ coefficients drops to 3 . As a result, the market and Fama and French models with GARCH(1,1)-M terms are less able to explain the momentum profits. Though largely insignificant in Table 4, the average abnormal returns of the momentum strategies equal 0.0125 a month for the $\mathrm{GARCH}(1,1)-\mathrm{M}$ market model and 0.0079 for the GARCH(1,1)-M Fama and French model. These average $\alpha$ coefficients are in excess of the 0.0016 and 0.0004 average abnormal return for the GJR-GARCH(1,1)-M market model and the GJR-GARCH(1,1)-M Fama and French model, respectively.

\footnotetext{
${ }^{11}$ We also examined a pure GJR-GARCH(1,1) - that is, a model without a conditional volatility term in the mean equation. However, unsurprisingly, it did not explain the observed momentum profits since in such a model, there is no linkage between the time-varying volatility and the returns. Therefore, the estimates from this model are not included in the paper, but are available from the authors on request.

${ }^{12}$ Again there are a few exceptions $\left(\gamma_{L}>\gamma_{W}\right.$ for the 3-3 and 3-12 winners of the conditional Fama and French model), but these are extremely rare.
} 
To summarize, the evidence in Tables 3 and 4 suggests that it is both the asymmetric response of the losers to good and bad news and the conditional risk premium that explain the profitability of the momentum strategies. Neither the leverage effect, nor the conditional risk premium in isolation can explain the abnormal performance of the momentum strategies. It is the interaction between two that drives the momentum returns.

To judge the relative merits of models (1) to (6), the Akaike information criterion (AIC) is calculated for the winners, losers and momentum portfolios. AIC trades off better model fit for greater numbers of parameters, and thus a preferred model is one with the lowest value of the criterion. The results are reported in Table 5 for different specifications of the market and Fama and French models. These specifications include the static models (1) and (2), the GJR-GARCH(1,1)-M models (3) and (4), and the GARCH(1,1)-M models (5) and (6). or a given specification of the riskreturn relationship, the data always favor the Fama and French model over the market model. This indicates that the size and book-to-market value risk factors add explanatory power to the models over and above that provided by the market return. More pertinent to our study, the data evidently prefer the GJR-GARCH(1,1)-M models to the static approaches. The GJR-GARCH(1,1)-M market and Fama and French models have the lowest AIC in the vast majority of the cases, and never rank last in terms of AIC. These results for the GJR-GARCH $(1,1)-\mathrm{M}$ models compare favorably to the AIC of the GARCH(1,1)-M. Irrespective of the ranking and holding periods, the static versions of the market and Fama and French model stand out as having the highest values of the AIC. This suggests that out of the three specifications of the market and Fama and French models, the static versions provide the worst account of the returns of the winner, loser and momentum portfolios, while the time-varying conditional volatility models allowing for asymmetries provide the best.

\section{Robustness of the results to the market examined}

In order to determine whether the ability of the asymmetric conditional volatility model to explain the results of the momentum portfolios results from some specific feature of the UK market, or whether it is likely to be more general, we repeat the entire analysis above on winner, loser and 
momentum portfolios formed from US stocks. The US data cover the period January 1978 to December 2001, and were obtained from Datastream. The mean returns of the winner, loser, and momentum portfolios, formed in an identical way to that described above for the UK market, are presented in Table 6. There is ample evidence of momentum effects, with the winner portfolio average returns statistically significantly exceeding those of the losers for all nine portfolio formation and holding periods examined. While the sizes of the momentum effects are slightly smaller for the US, they are of the same order of magnitude as they were for the UK. For example, for the $(12,12)$ horizon, the average monthly return for the UK was $1.43 \%$, and for the US it is $1.12 \%$. For the latter market, profitability is highest at $1.71 \%$ per month for the $(12,3)$ strategy, whereas it was maximized at $1.93 \%$ for the $(6,6)$ strategy in the UK.

Table 7 reports the parameter estimates for the statistic market and Fama-French models using the US data. It is evident that the 3-factor model is no more able to explain the profitability of relative strength portfolios for this market than it was for the UK. For all nine (eight of the nine) combinations of portfolio formation and holding periods examined, the momentum profits are still positive and statistically significant at the 5\% (1\%) level.

Finally, Table 8 shows the parameters for the conditional market and Fama and French models with a GJR-GARCH $(1,1)-\mathrm{M}$ term estimated using US Data. While the importance of timevarying unsystematic risk appears more uniformly high whatever combination of portfolio formation and holding period are used in the UK context than for the US, in the latter case, the momentum profits are again largely explained by the incorporation of the unsystematic risk terms into the equations. This leads both the sizes of the estimated alphas and their levels of statistical significance to reduce. For instance, when the time-varying unsystematic risk terms are included in the model, the alpha for the $(6,6)$ momentum strategy of 0.0134 when the market model is used is reduced by $40 \%$ to 0.085 and it is reduced by $25 \%$ to 0.012 when the Fama-French model is used. For the augmented market models presented, only one, the $(6,12)$ strategy, is significantly profitable at the $5 \%$ level, and none are profitable at the $1 \%$ level; similarly, only one combination of formation and holding periods leads to significant alpha when the Fama-French model is augmented 
by the inclusion of the conditional unsystematic risk term. ${ }^{13}$ Our other major findings concerning the speed of adjustment of volatility and the asymmetric response of volatility to good and bad news for the winners relative to the losers still holds.

\section{Conclusions}

This article considers whether the widely documented momentum profits are a compensation for time-varying unsystematic risk as described by the family of autoregressive conditionally heteroscedastic models. The motivation for estimating a GJR-GARCH(1,1)-M model stems from the fact that since losers have a higher probability than winners to disclose bad news, one cannot assume a symmetric response of volatility to good and bad news. Neither can we presuppose that the speed of adjustment of volatility to news is the same for the winners and the losers. Such a suggestion is consistent with the findings of Hong et al. (2000) that for firms with no or low analysts coverage, bad news travels slower than good news and thus, the volatility of the losers may respond more slowly to news than that of the winners. Our results suggest that the timevarying unsystematic volatility of the winners indeed differs from that of the losers. For example, the volatility of the winners is found to be more sensitive to recent news and less persistent than that of the losers. The converse, that the volatility of the losers is found to be more sensitive to distant news and more persistent than that of the winners, also holds. Future research may ascertain the precise cause of these findings, and in particular whether they are best attributed to rational, riskbased or behavioral causes. But we conjecture that the time-varying risk of companies with no or low analyst coverage depends on the nature of the information that is been disclosed: Good news is disclosed earlier, and impacts volatility sooner, than bad news. Relative to the volatility of the winners, that of the losers also clearly shows a more asymmetric response to good and bad news. As losers have a higher propensity to disclose bad news, negative return shocks increase their volatility more than they increase that of winners.

\footnotetext{
${ }^{13}$ Again, similar results are found, but not reported here, for the symmetric GARCH-M formulation.
} 
Most importantly, we also document that the GJR-GARCH(1,1)-M models explain much of the profitability of the momentum strategies, and certainly have more descriptive power than the commonly used size and value risk factors. Interestingly, neither the GJR-GARCH(1,1) nor the GARCH(1,1)-M specifications alone could account for the abnormal return of the relative-strength portfolios. It is therefore a combination of the asymmetric response of the losers to good and bad news, the sluggish response of losers to bad news and the conditional risk premium embedded in the $\mathrm{GARCH}(1,1)-\mathrm{M}$ model, that explain the profitability of the relative-strength portfolios. 


\section{References}

Andersen, T. G., Bollerslev, T., Christoffersen, P. F., Diebold, F. X. 2006. Volatility and correlation forecasting. In G. Elliott, C. W. J. Granger and A. Timmermann Eds.. Handbook of Economic Forecasting 778--878. Amsterdam: North-Holland.

Barberis, N, Schleifer, A., Vishny, R., 1998, A model of investor sentiment. Journal of Financial Economics 49, 307--343.

Bauwens, L., Laurent, S., Rombouts, J. V. K., 2006. Multivariate GARCH models: A survey. Journal of Applied Econometrics 21, 79--109.

Carhart, M. (1997) On Persistence in Mutual Fund Performance. Journal of Finance 52, 57-82.

Chan L. K. C., Jegadeesh, N., Lakonishok, J., 1996. Momentum strategies. Journal of Finance 51, 1681--1713.

Chen, H-L., De Bondt, W., 2004. Style momentum within the S\&P-500 index. Journal of Empirical Finance 11, 483--507.

Chen, N-F., Roll, R., Ross, S. A., 1986. Economic forces and the stock market. Journal of Business 59, 383--403.

Chordia T, Shivakumar, L., 2002. Momentum, business cycle and time-varying expected returns. Journal of Finance 57, 985--1018.

Daniel, K, Hirshleifer, D., Subrahmanyam, A., 1998. Investor psychology and security market under- and overreactions. Journal of Finance 53, 1839--1885.

Ellis, M., Thomas, D. C., 2003. Momentum and the FTSE 350. Journal of Asset Management 5, 25-36 .

Engle, R. F., 1982. Autoregressive conditional heteroscedasticity with estimates of the variance of UK inflation. Econometrica 50, 987--1008.

Fama, E. F., French, K., 1993. Common risk factors in the returns on stocks and bonds. Journal of Financial Economics 33, 3--56.

Fama, E. F., French, K., 1996. Multifactor explanations of asset pricing anomalies. Journal of Finance 51, 55--84.

Glosten L. R., Jagannathan, R., Runkle, D. E., 1993. On the relation between the expected value and the volatility of the nominal excess return on stocks. Journal of Finance 48, 1779--1801.

Griffin, J. M., Ji, X., Martin, S., 2003. Momentum investing and business cycle risk: Evidence from pole to pole. Journal of Finance 58, 2515--2547.

Grundy B. D., Martin, J. S., 2001. Understanding the nature of the risks and the source of the rewards to momentum investing. Review of Financial Studies 14, 1, 29--78.

Hong, H., Lim, T., Stein, J., 2000. Bad news travels slowly: Size, analyst coverage, and the profitability of momentum strategies. Journal of Finance 55, 265--295. 
Hong, H., Stein, J., 1999. A unified theory of underreaction, momentum trading and overreaction in asset markets. Journal of Finance 54, 2143--2184.

Jegadeesh, N., Titman, S., 1993. Returns to buying winners and selling losers: Implications for stock market efficiency. Journal of Finance 48, 65--91.

Jegadeesh, N., Titman, S., 2001. Profitability of momentum strategies: An evaluation of alternative explanations. Journal of Finance 56, 699--720.

Karolyi, A., Kho, B-C., 2004. Momentum strategies: Some bootstrap tests. Journal of Empirical Finance 11, 509--534.

Lesmond, D. A., Schill, M. J., Zhou, C., 2004. The illusory nature of momentum profits. Journal of Financial Economics 71, 349--380.

Liu W., Strong, N., Xu, X., 1999. The profitability of momentum investing. Journal of Business Finance and Accounting 26, 1043--1091.

Moskowitz, T. J., Grinblatt, M., 1999. Do industries explain momentum?. Journal of Finance 54, 1249--1290.

Nagel, S., Lewellen, J., 2006. The conditional CAPM does not explain asset pricing anomalies. Journal of Financial Economics forthcoming.

Nelson D. B., 1991. Conditional heteroskedasticity in asset returns: A new approach. Econometrica 59, 347--370.

Okunev, J., White, D., 2003. Do momentum-based strategies still work in foreign currency markets?. Journal of Financial and Quantitative Analysis 38, 425--447.

Poon, S. H., Granger, C. W. J., 2003. Forecasting volatility in financial markets: A review. Journal of Economic Literature 41, 478--539.

Rabemananjara R., Zakoian, J. M., 1993. Threshold ARCH models and asymmetries in volatility. Journal of Applied Econometrics 8, 31--49.

Sadka, R., 2006. Momentum and post-earnings-announcement drift anomalies: The role of liquidity risk. Journal of Financial Economics forthcoming.

Sharpe, W. F., 1964. Capital asset prices: A theory of market equilibrium under. conditions of risk. Journal of Finance 19, 425--442.

Wang, K. Q., 2003. Asset pricing with conditional information: A new test. Journal of Finance 58, $161--195$.

Wu, X., 2002. A conditional multifactor model of return momentum. Journal of Banking and Finance 26, 1675--1696. 


\section{Table 1 - Summary statistics of the returns of the winner, loser and momentum portfolios}

Winner (Loser) is an equally-weighted non-overlapping portfolio containing the $10 \%$ of stocks that performed the best (worst) over a given ranking period. Momentum is a portfolio that buys the winner portfolio and sells the loser portfolio short. Returns are measured as proportions rather than percentages. Reward-to-risk ratio is the ratio of the monthly mean to the monthly standard deviation. The $p$-values in parentheses are for the significance of the mean. They are based on heteroscedasticity and autocorrelation robust (Newey-West) standard errors.

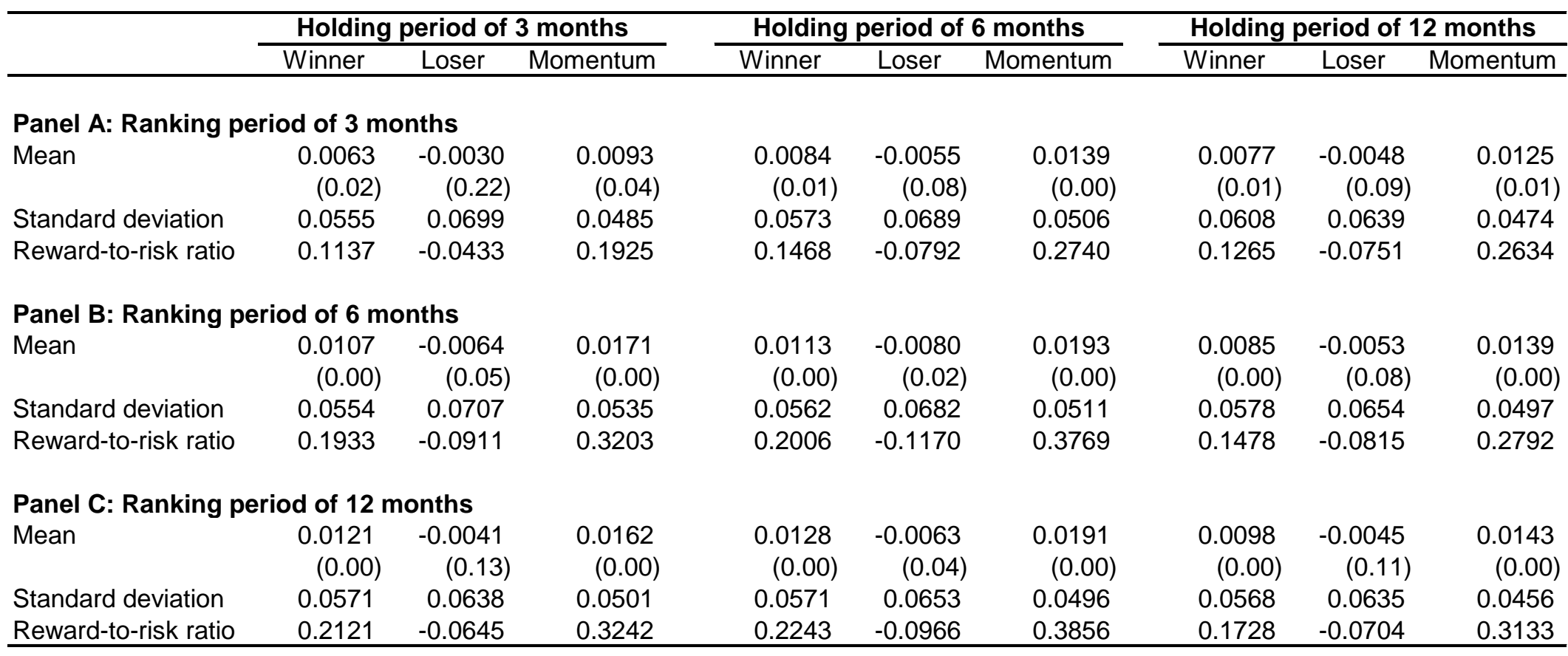




\section{Table 2 - Static market and Fama and French models}

The table reports coefficient estimates for equations (1) and (2) for the winner, loser and momentum portfolios. Winner (Loser) is an equally-weighted non-overlapping portfolio containing the $10 \%$ of stocks that performed the best (worst) over a given ranking period. Momentum is a portfolio that buys the winner portfolio and short sells the loser portfolio. $\alpha$ measures the portfolio's abnormal performance, $\beta$ measures the market risk of the portfolio, $s$ and $h$ are the portfolio loadings on the size and book-to-market value factors as measured by Fama and French (1993). MM refers to the market model and FFM refers to the Fama and French model. White's heteroscedasticity robust $t$ statistics are in parentheses.

\begin{tabular}{|c|c|c|c|c|c|c|c|c|c|c|c|c|c|c|c|c|c|c|}
\hline & \multicolumn{6}{|c|}{ Holding period of 3 months } & \multicolumn{6}{|c|}{ Holding period of 6 months } & \multicolumn{6}{|c|}{ Holding period of 12 months } \\
\hline & \multicolumn{2}{|c|}{ Winner } & \multicolumn{2}{|c|}{ Loser } & \multicolumn{2}{|c|}{ Momentum } & \multicolumn{2}{|c|}{ Winner } & \multicolumn{2}{|c|}{ Loser } & \multicolumn{2}{|c|}{ Momentum } & \multicolumn{2}{|c|}{ Winner } & \multicolumn{2}{|c|}{ Loser } & \multicolumn{2}{|c|}{ Momentum } \\
\hline & $\mathrm{MM}$ & FFM & $\mathrm{MM}$ & FFM & $\mathrm{MM}$ & FFM & $\mathrm{MM}$ & FFM & $\mathrm{MM}$ & FFM & $\mathrm{MM}$ & FFM & $\mathrm{MM}$ & FFM & $\mathrm{MM}$ & FFM & $\mathrm{MM}$ & FFM \\
\hline \multicolumn{19}{|c|}{ Panel A: Ranking period of 3 months } \\
\hline$\alpha$ & $\begin{array}{r}-0.0020 \\
(-0.87)\end{array}$ & $\begin{array}{r}-0.0031 \\
(-2.33)\end{array}$ & $\begin{array}{r}-0.0115 \\
(-3.81)\end{array}$ & $\begin{array}{r}-0.0141 \\
(-6.24)\end{array}$ & $\begin{array}{r}0.0095 \\
(3.46)\end{array}$ & $\begin{array}{c}0.0110 \\
(4.11)\end{array}$ & $\begin{array}{r}0.0001 \\
(0.03)\end{array}$ & $\begin{array}{r}-0.0009 \\
(-0.71)\end{array}$ & $\begin{array}{r}-0.0139 \\
(-4.59)\end{array}$ & $\begin{array}{r}-0.0170 \\
(-7.80)\end{array}$ & $\begin{array}{r}0.0140 \\
(4.82)\end{array}$ & $\begin{array}{c}0.0161 \\
(6.05)\end{array}$ & $\begin{array}{r}-0.0007 \\
(-0.28)\end{array}$ & $\begin{array}{c}-0.0014 \\
(-1.01)\end{array}$ & $\begin{array}{r}-0.0132 \\
(-4.68)\end{array}$ & $\begin{array}{r}-0.0166 \\
(-8.49)\end{array}$ & $\begin{array}{r}0.0125 \\
(4.60)\end{array}$ & $\begin{array}{c}0.0152 \\
(6.47)\end{array}$ \\
\hline$\beta$ & $\begin{array}{c}0.7662 \\
(11.79)\end{array}$ & $\begin{array}{l}0.9660 \\
(26.08)\end{array}$ & $\begin{array}{l}0.9155 \\
(12.15)\end{array}$ & $\begin{array}{l}1.1528 \\
(13.64)\end{array}$ & $\begin{array}{r}-0.1493 \\
(-1.62)\end{array}$ & $\begin{array}{r}-0.1868 \\
(-1.73)\end{array}$ & $\begin{array}{l}0.7833 \\
(11.35)\end{array}$ & $\begin{array}{l}0.9856 \\
(22.83)\end{array}$ & $\begin{array}{l}0.8858 \\
(12.06)\end{array}$ & $\begin{array}{l}1.1360 \\
(13.77)\end{array}$ & $\begin{array}{r}-0.1025 \\
(-1.11)\end{array}$ & $\begin{array}{r}-0.1505 \\
(-1.39)\end{array}$ & $\begin{array}{l}0.8358 \\
(16.03)\end{array}$ & $\begin{array}{l}1.0392 \\
(29.46)\end{array}$ & $\begin{array}{l}0.8237 \\
(12.24)\end{array}$ & $\begin{array}{l}1.0707 \\
(17.58)\end{array}$ & $\begin{array}{c}0.0121 \\
(0.23)\end{array}$ & $\begin{array}{r}-0.0314 \\
(-0.49)\end{array}$ \\
\hline & - & $\begin{array}{l}1.0001 \\
(17.45)\end{array}$ & - & $\begin{array}{l}1.1143 \\
(11.98)\end{array}$ & - & $\begin{array}{r}-0.1142 \\
(-0.89)\end{array}$ & - & $\begin{array}{l}1.0195 \\
(16.45)\end{array}$ & - & $\begin{array}{l}1.1563 \\
(12.72)\end{array}$ & - & $\begin{array}{r}-0.1368 \\
(-1.05)\end{array}$ & - & $\begin{array}{l}1.0439 \\
(17.23)\end{array}$ & - & $\begin{array}{l}1.1184 \\
(14.98)\end{array}$ & - & $\begin{array}{r}-0.0745 \\
(-0.69)\end{array}$ \\
\hline$h$ & - & $\begin{array}{r}-0.1160 \\
(-1.43)\end{array}$ & - & $\begin{array}{c}0.2598 \\
(1.69)\end{array}$ & - & $\begin{array}{r}-0.3759 \\
(-2.05)\end{array}$ & - & $\begin{array}{r}-0.1529 \\
(-1.58)\end{array}$ & - & $\begin{array}{c}0.3770 \\
(2.23)\end{array}$ & - & $\begin{array}{r}-0.5300 \\
(-2.36)\end{array}$ & - & $\begin{array}{r}-0.2563 \\
(-2.10)\end{array}$ & - & $\begin{array}{c}0.4934 \\
(4.32)\end{array}$ & - & $\begin{array}{r}-0.7497 \\
(-4.04)\end{array}$ \\
\hline \multicolumn{19}{|c|}{ Panel B: Ranking period of 6 months } \\
\hline$\alpha$ & $\begin{array}{c}0.0024 \\
(1.05)\end{array}$ & $\begin{array}{c}0.0017 \\
(1.34)\end{array}$ & $\begin{array}{r}-0.0149 \\
(-4.78)\end{array}$ & $\begin{array}{r}-0.0182 \\
(-7.89)\end{array}$ & $\begin{array}{r}0.0173 \\
(5.67)\end{array}$ & $\begin{array}{c}0.0200 \\
(7.03)\end{array}$ & $\begin{array}{r}0.0029 \\
(1.28)\end{array}$ & $\begin{array}{c}0.0021 \\
(1.75)\end{array}$ & $\begin{array}{r}-0.0164 \\
(-5.42)\end{array}$ & $\begin{array}{r}-0.0198 \\
(-9.03)\end{array}$ & $\begin{array}{c}0.0194 \\
(6.60)\end{array}$ & $\begin{array}{c}0.0219 \\
(8.13)\end{array}$ & $\begin{array}{r}0.0002 \\
(0.07)\end{array}$ & $\begin{array}{r}-0.0005 \\
(-0.39)\end{array}$ & $\begin{array}{r}-0.0138 \\
(-4.77)\end{array}$ & $\begin{array}{r}-0.0173 \\
(-8.32)\end{array}$ & $\begin{array}{r}0.0139 \\
(4.89)\end{array}$ & $\begin{array}{c}0.0169 \\
(6.64)\end{array}$ \\
\hline$\beta$ & $\begin{array}{l}0.7751 \\
(11.28)\end{array}$ & $\begin{array}{l}0.9601 \\
(22.13)\end{array}$ & $\begin{array}{l}0.9017 \\
(11.78)\end{array}$ & $\begin{array}{l}1.1525 \\
(13.31)\end{array}$ & $\begin{array}{r}-0.1266 \\
(-1.29)\end{array}$ & $\begin{array}{r}-0.1924 \\
(-1.64)\end{array}$ & $\begin{array}{l}0.7936 \\
(11.87)\end{array}$ & $\begin{array}{l}0.9846 \\
(22.39)\end{array}$ & $\begin{array}{l}0.8677 \\
(11.77)\end{array}$ & $\begin{array}{l}1.1181 \\
(13.77)\end{array}$ & $\begin{array}{r}-0.0742 \\
(-0.80)\end{array}$ & $\begin{array}{c}-0.1334 \\
(-1.21)\end{array}$ & $\begin{array}{l}0.8188 \\
(15.39)\end{array}$ & $\begin{array}{l}1.0099 \\
(31.08)\end{array}$ & $\begin{array}{l}0.8451 \\
(12.09)\end{array}$ & $\begin{array}{l}1.0899 \\
(15.50)\end{array}$ & $\begin{array}{r}-0.0263 \\
(-0.39)\end{array}$ & $\begin{array}{r}-0.0800 \\
(-0.94)\end{array}$ \\
\hline 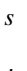 & - & $\begin{array}{l}0.9475 \\
(16.84)\end{array}$ & - & $\begin{array}{l}1.1450 \\
(12.04)\end{array}$ & - & $\begin{array}{r}-0.1975 \\
(-1.49)\end{array}$ & - & $\begin{array}{l}0.9716 \\
(17.19)\end{array}$ & - & $\begin{array}{l}1.1375 \\
(12.87)\end{array}$ & - & $\begin{array}{r}-0.1659 \\
(-1.31)\end{array}$ & - & $\begin{array}{l}0.9807 \\
(17.65)\end{array}$ & - & $\begin{array}{l}1.0960 \\
(13.59)\end{array}$ & - & $\begin{array}{r}-0.1153 \\
(-0.99)\end{array}$ \\
\hline$h$ & - & $\begin{array}{r}-0.2210 \\
(-2.47)\end{array}$ & - & $\begin{array}{c}0.4528 \\
(2.57)\end{array}$ & - & $\begin{array}{r}-0.6738 \\
(-2.89)\end{array}$ & - & $\begin{array}{r}-0.1910 \\
(-2.26)\end{array}$ & - & $\begin{array}{c}0.4799 \\
(2.79)\end{array}$ & - & $\begin{array}{r}-0.6709 \\
(-3.03)\end{array}$ & - & $\begin{array}{r}-0.2395 \\
(-2.21)\end{array}$ & - & $\begin{array}{c}0.5575 \\
(4.27)\end{array}$ & - & $\begin{array}{r}-0.7971 \\
(-3.92)\end{array}$ \\
\hline \multicolumn{19}{|c|}{ Panel C: Ranking period of 12 months } \\
\hline$\alpha$ & $\begin{array}{r}0.0037 \\
(1.69)\end{array}$ & $\begin{array}{c}0.0033 \\
(2.68)\end{array}$ & $\begin{array}{r}-0.0125 \\
(-4.46)\end{array}$ & $\begin{array}{r}-0.0155 \\
(-7.06)\end{array}$ & $\begin{array}{r}0.0162 \\
(5.63)\end{array}$ & $\begin{array}{c}0.0188 \\
(7.02)\end{array}$ & $\begin{array}{r}0.0044 \\
(2.00)\end{array}$ & $\begin{array}{c}0.0039 \\
(3.32)\end{array}$ & $\begin{array}{r}-0.0147 \\
(-5.01)\end{array}$ & $\begin{array}{r}-0.0183 \\
(-8.66)\end{array}$ & $\begin{array}{r}0.0191 \\
(6.68)\end{array}$ & $\begin{array}{c}0.0222 \\
(8.69)\end{array}$ & $\begin{array}{r}0.0014 \\
(0.64)\end{array}$ & $\begin{array}{c}0.0008 \\
(0.76)\end{array}$ & $\begin{array}{r}-0.0129 \\
(-4.59)\end{array}$ & $\begin{array}{r}-0.0165 \\
(-8.53)\end{array}$ & $\begin{array}{r}0.0142 \\
(5.48)\end{array}$ & $\begin{array}{c}0.0174 \\
(7.73)\end{array}$ \\
\hline$\beta$ & $\begin{array}{l}0.8525 \\
(13.71)\end{array}$ & $\begin{array}{l}1.0210 \\
(24.79)\end{array}$ & $\begin{array}{l}0.8270 \\
(10.89)\end{array}$ & $\begin{array}{l}1.0435 \\
(11.54)\end{array}$ & $\begin{array}{r}0.0255 \\
(0.27)\end{array}$ & $\begin{array}{r}-0.0225 \\
(-0.19)\end{array}$ & $\begin{array}{l}0.8480 \\
(13.62)\end{array}$ & $\begin{array}{l}1.0232 \\
(24.14)\end{array}$ & $\begin{array}{l}0.8214 \\
(10.48)\end{array}$ & $\begin{array}{l}1.0707 \\
(11.58)\end{array}$ & $\begin{array}{r}0.0265 \\
(0.27)\end{array}$ & $\begin{array}{r}-0.0475 \\
(-0.40)\end{array}$ & $\begin{array}{l}0.8468 \\
(16.15)\end{array}$ & $\begin{array}{l}1.0259 \\
(35.74)\end{array}$ & $\begin{array}{l}0.8164 \\
(12.47)\end{array}$ & $\begin{array}{l}1.0599 \\
(16.48)\end{array}$ & $\begin{array}{r}0.0304 \\
(0.51)\end{array}$ & $\begin{array}{r}-0.0340 \\
(-0.46)\end{array}$ \\
\hline$s$ & - & $\begin{array}{l}0.8763 \\
(16.97)\end{array}$ & - & $\begin{array}{l}0.9803 \\
(10.73)\end{array}$ & - & $\begin{array}{r}-0.1040 \\
(-0.84)\end{array}$ & - & $\begin{array}{l}0.9036 \\
(17.08)\end{array}$ & - & $\begin{array}{l}1.1168 \\
(12.35)\end{array}$ & - & $\begin{array}{r}-0.2132 \\
(-1.73)\end{array}$ & - & $\begin{array}{l}0.9200 \\
(18.87)\end{array}$ & - & $\begin{array}{l}1.0835 \\
(14.96)\end{array}$ & - & $\begin{array}{r}-0.1635 \\
(-1.71)\end{array}$ \\
\hline$h$ & - & $\begin{array}{r}-0.2726 \\
(-2.97) \\
\end{array}$ & - & $\begin{array}{r}0.4346 \\
(3.35) \\
\end{array}$ & - & $\begin{array}{r}-0.7072 \\
(-4.07) \\
\end{array}$ & - & $\begin{array}{c}-0.2434 \\
(-2.57) \\
\end{array}$ & - & $\begin{array}{c}0.5625 \\
(4.56) \\
\end{array}$ & - & $\begin{array}{r}-0.8059 \\
(-4.71) \\
\end{array}$ & - & $\begin{array}{r}-0.2283 \\
(-2.43) \\
\end{array}$ & - & $\begin{array}{c}0.5925 \\
(5.13) \\
\end{array}$ & - & $\begin{array}{r}-0.8208 \\
(-4.91) \\
\end{array}$ \\
\hline
\end{tabular}




\section{Table 3 - Conditional market and Fama and French models with a GJR-GARCH (1, 1)-M term}

The table reports coefficient estimates for systems (3) and (4) for the winner, loser and momentum portfolios. Winner (Loser) is an equallyweighted non-overlapping portfolio containing the $10 \%$ of stocks that performed the best (worst) over a given ranking period. Momentum is a portfolio that buys the winner portfolio and short sells the loser portfolio. $\alpha$ measures the portfolio's abnormal performance, $\beta$ measures the market risk of the portfolio, $s$ and $h$ are the portfolio loadings on the size and book-to-market value factors as measured by Fama and French (1993), $\delta \sigma_{t}$ is the time-varying risk exposure. The conditional variance of the portfolio returns follows a GJR-GARCH(1,1) structure as $\sigma_{t}^{2}=\omega+\gamma \varepsilon_{t-1}^{2}+\eta I_{t-1} \varepsilon_{t-1}^{2}+\theta \sigma_{t-1}^{2}$, where $\omega, \gamma, \eta$ and $\theta$ are estimated parameters and $I_{t-1}$ takes a value of 1 , when $\varepsilon_{t-1}$ is negative and a value of 0 , otherwise. MM refers to the market model and FFM refers to the Fama and French model. Bollerslev-Wooldridge robust $t$-statistics are in parentheses.

\begin{tabular}{|c|c|c|c|c|c|c|c|c|c|c|c|c|c|c|c|c|c|c|}
\hline & \multicolumn{6}{|c|}{ Holding period of 3 months } & \multicolumn{6}{|c|}{ Holding period of 6 months } & \multicolumn{6}{|c|}{ Holding period of 12 months } \\
\hline & \multicolumn{2}{|c|}{ Winner } & \multicolumn{2}{|c|}{ Loser } & \multicolumn{2}{|c|}{ Momentum } & \multicolumn{2}{|c|}{ Winner } & \multicolumn{2}{|c|}{ Loser } & \multicolumn{2}{|c|}{ Momentum } & \multicolumn{2}{|c|}{ Winner } & \multicolumn{2}{|c|}{ Loser } & \multicolumn{2}{|c|}{ Momentum } \\
\hline & $\mathrm{MM}$ & FFM & $\mathrm{MM}$ & FFM & $\mathrm{MM}$ & FFM & MM & FFM & $\mathrm{MM}$ & FFM & MM & FFM & $\mathrm{MM}$ & FFM & $\mathrm{MM}$ & FFM & $\mathrm{MM}$ & FFM \\
\hline \multicolumn{19}{|c|}{ Panel A: Ranking period of 3 months } \\
\hline$\alpha$ & $\begin{array}{r}-0.0015 \\
(-0.17)\end{array}$ & $\begin{array}{r}0.0164 \\
(2.48)\end{array}$ & $\begin{array}{r}-0.0090 \\
(-1.41)\end{array}$ & $\begin{array}{r}0.0106 \\
(1.67)\end{array}$ & $\begin{array}{r}-0.0028 \\
(-0.44)\end{array}$ & $\begin{array}{c}-0.0007 \\
(-0.10)\end{array}$ & $\begin{array}{r}0.0094 \\
(1.55)\end{array}$ & $\begin{array}{r}0.0073 \\
(2.15)\end{array}$ & $\begin{array}{r}0.0501 \\
(2.64)\end{array}$ & $\begin{array}{r}0.0084 \\
(1.74)\end{array}$ & $\begin{array}{r}-0.0013 \\
(-0.19)\end{array}$ & $\begin{array}{c}0.0027 \\
(0.48)\end{array}$ & $\begin{array}{r}0.0016 \\
(0.27)\end{array}$ & $\begin{array}{r}0.0215 \\
(3.11)\end{array}$ & $\begin{array}{c}0.0514 \\
(10.02)\end{array}$ & $\begin{array}{r}0.0178 \\
(2.14)\end{array}$ & $\begin{array}{c}0.0011 \\
(0.21)\end{array}$ & $\begin{array}{c}0.0024 \\
(0.45)\end{array}$ \\
\hline$\beta$ & $\begin{array}{c}0.7049 \\
(14.87)\end{array}$ & $\begin{array}{l}0.9410 \\
(34.29)\end{array}$ & $\begin{array}{c}0.7786 \\
(15.71)\end{array}$ & $\begin{array}{l}1.0329 \\
(15.89)\end{array}$ & $\begin{array}{r}-0.0633 \\
(-1.67)\end{array}$ & $\begin{array}{r}-0.1510 \\
(-3.61)\end{array}$ & $\begin{array}{l}0.6659 \\
(22.31)\end{array}$ & $\begin{array}{l}0.8707 \\
(28.14)\end{array}$ & $\begin{array}{l}0.7589 \\
(19.30)\end{array}$ & $\begin{array}{l}1.0316 \\
(21.94)\end{array}$ & $\begin{array}{r}-0.0436 \\
(-0.90)\end{array}$ & $\begin{array}{r}-0.1760 \\
(-4.22)\end{array}$ & $\begin{array}{l}0.7367 \\
(24.08)\end{array}$ & $\begin{array}{l}1.0186 \\
(27.37)\end{array}$ & $\begin{array}{l}0.6933 \\
(45.65)\end{array}$ & $\begin{array}{l}0.9444 \\
(38.61)\end{array}$ & $\begin{array}{c}0.0664 \\
(2.19)\end{array}$ & $\begin{array}{c}0.0191 \\
(0.61)\end{array}$ \\
\hline$s$ & - & $\begin{array}{l}0.8956 \\
(21.85)\end{array}$ & - & $\begin{array}{l}1.0740 \\
(18.48)\end{array}$ & - & $\begin{array}{r}-0.2388 \\
(-3.56)\end{array}$ & - & $\begin{array}{l}0.8066 \\
(21.36)\end{array}$ & - & $\begin{array}{l}1.1024 \\
(22.51)\end{array}$ & - & $\begin{array}{r}-0.3119 \\
(-4.91)\end{array}$ & & $\begin{array}{c}0.9423 \\
(25.19)\end{array}$ & & $\begin{array}{l}1.0383 \\
(23.53)\end{array}$ & - & $\begin{array}{r}-0.1345 \\
(-2.38)\end{array}$ \\
\hline$h$ & - & $\begin{array}{r}0.0682 \\
(1.07)\end{array}$ & - & $\begin{array}{r}0.3588 \\
(4.43)\end{array}$ & - & $\begin{array}{r}-0.2807 \\
(-3.23)\end{array}$ & - & $\begin{array}{r}0.1173 \\
(2.42)\end{array}$ & - & $\begin{array}{r}0.4939 \\
(6.92)\end{array}$ & - & $\begin{array}{r}-0.4083 \\
(-4.34)\end{array}$ & & $\begin{array}{r}0.1296 \\
(2.10)\end{array}$ & & $\begin{array}{r}0.4544 \\
(8.39)\end{array}$ & - & $\begin{array}{r}-0.2687 \\
(-3.87)\end{array}$ \\
\hline$\delta$ & $\begin{array}{r}-0.0232 \\
(-0.08)\end{array}$ & $\begin{array}{r}-0.9622 \\
(-2.66)\end{array}$ & $\begin{array}{r}-0.0102 \\
(-0.07)\end{array}$ & $\begin{array}{r}-0.6502 \\
(-3.31)\end{array}$ & $\begin{array}{c}0.3038 \\
(1.65)\end{array}$ & $\begin{array}{r}0.2897 \\
(1.49)\end{array}$ & $\begin{array}{r}-0.2304 \\
(-1.11)\end{array}$ & $\begin{array}{r}-0.3971 \\
(-2.05)\end{array}$ & $\begin{array}{r}-1.3282 \\
(-3.34)\end{array}$ & $\begin{array}{r}-0.7437 \\
(-4.33)\end{array}$ & $\begin{array}{c}0.3280 \\
(1.63)\end{array}$ & $\begin{array}{c}0.3141 \\
(1.78)\end{array}$ & $\begin{array}{r}-0.0387 \\
(-0.20)\end{array}$ & $\begin{array}{r}-1.1028 \\
(-3.17)\end{array}$ & $\begin{array}{r}-1.3747 \\
(-7.91)\end{array}$ & $\begin{array}{r}-1.1255 \\
(-3.39)\end{array}$ & $\begin{array}{c}0.3497 \\
(2.09)\end{array}$ & $\begin{array}{c}0.3437 \\
(1.91)\end{array}$ \\
\hline$\omega$ & $\begin{array}{c}0.0003 \\
(2.90)\end{array}$ & $\begin{array}{r}0.0001 \\
(2.42)\end{array}$ & $\begin{array}{r}0.0001 \\
(1.12)\end{array}$ & $\begin{array}{c}0.0001 \\
(1.45)\end{array}$ & $\begin{array}{c}0.0001 \\
(1.63)\end{array}$ & $\begin{array}{c}0.0001 \\
(1.42)\end{array}$ & $\begin{array}{r}0.0003 \\
(3.02)\end{array}$ & $\begin{array}{c}0.0001 \\
(3.48)\end{array}$ & $\begin{array}{r}0.0001 \\
(1.69)\end{array}$ & $\begin{array}{r}0.0000 \\
(1.48)\end{array}$ & $\begin{array}{c}0.0001 \\
(1.64)\end{array}$ & $\begin{array}{c}0.0001 \\
(1.51)\end{array}$ & $\begin{array}{c}0.0001 \\
(2.00)\end{array}$ & $\begin{array}{c}0.0001 \\
(1.58)\end{array}$ & $\begin{array}{r}0.0000 \\
(-0.12)\end{array}$ & $\begin{array}{r}0.0001 \\
(2.27)\end{array}$ & $\begin{array}{c}0.0001 \\
(1.48)\end{array}$ & $\begin{array}{c}0.0001 \\
(1.42)\end{array}$ \\
\hline$\gamma$ & $\begin{array}{r}0.3542 \\
(3.09)\end{array}$ & $\begin{array}{r}0.1560 \\
(2.49)\end{array}$ & $\begin{array}{r}0.1181 \\
(1.73)\end{array}$ & $\begin{array}{r}0.1048 \\
(1.24)\end{array}$ & $\begin{array}{c}0.5210 \\
(2.75)\end{array}$ & $\begin{array}{r}0.4146 \\
(2.56)\end{array}$ & $\begin{array}{r}0.4488 \\
(2.52)\end{array}$ & $\begin{array}{r}0.4621 \\
(2.65)\end{array}$ & $\begin{array}{r}-0.0353 \\
(-2.63)\end{array}$ & $\begin{array}{r}0.0822 \\
(1.32)\end{array}$ & $\begin{array}{c}0.4492 \\
(3.45)\end{array}$ & $\begin{array}{r}0.4765 \\
(3.97)\end{array}$ & $\begin{array}{c}0.3051 \\
(2.72)\end{array}$ & $\begin{array}{c}0.2451 \\
(2.15)\end{array}$ & $\begin{array}{r}-0.0062 \\
(-0.53)\end{array}$ & $\begin{array}{r}-0.0193 \\
(-0.56)\end{array}$ & $\begin{array}{r}0.3628 \\
(2.89)\end{array}$ & $\begin{array}{r}0.2953 \\
(2.94)\end{array}$ \\
\hline$\eta$ & $\begin{array}{r}-0.2856 \\
(-2.15)\end{array}$ & $\begin{array}{r}0.0013 \\
(0.02)\end{array}$ & $\begin{array}{r}0.0789 \\
(1.11)\end{array}$ & $\begin{array}{r}0.1789 \\
(2.06)\end{array}$ & $\begin{array}{r}-0.4254 \\
(-2.41)\end{array}$ & $\begin{array}{r}-0.3469 \\
(-2.26)\end{array}$ & $\begin{array}{r}-0.0749 \\
(-0.41)\end{array}$ & $\begin{array}{r}-0.1226 \\
(-0.42)\end{array}$ & $\begin{array}{r}0.2155 \\
(3.24)\end{array}$ & $\begin{array}{r}0.2714 \\
(2.63)\end{array}$ & $\begin{array}{r}-0.2984 \\
(-2.46)\end{array}$ & $\begin{array}{r}-0.3134 \\
(-2.60)\end{array}$ & $\begin{array}{r}-0.0899 \\
(-0.83)\end{array}$ & $\begin{array}{r}-0.1568 \\
(-1.31)\end{array}$ & $\begin{array}{r}0.4319 \\
(6.97)\end{array}$ & $\begin{array}{c}0.3321 \\
(3.12)\end{array}$ & $\begin{array}{r}-0.2407 \\
(-2.23)\end{array}$ & $\begin{array}{r}-0.1710 \\
(-1.88)\end{array}$ \\
\hline$\theta$ & $\begin{array}{r}0.5871 \\
(5.71)\end{array}$ & $\begin{array}{l}0.7288 \\
(10.06)\end{array}$ & $\begin{array}{l}0.8325 \\
(12.84)\end{array}$ & $\begin{array}{r}0.7560 \\
(7.88)\end{array}$ & $\begin{array}{c}0.6846 \\
(6.79)\end{array}$ & $\begin{array}{r}0.7443 \\
(7.84)\end{array}$ & $\begin{array}{r}0.4310 \\
(4.21)\end{array}$ & $\begin{array}{r}0.4042 \\
(3.18)\end{array}$ & $\begin{array}{l}0.8770 \\
(16.21)\end{array}$ & $\begin{array}{l}0.7762 \\
(12.95)\end{array}$ & $\begin{array}{c}0.6603 \\
(5.72)\end{array}$ & $\begin{array}{c}0.6657 \\
(7.39)\end{array}$ & $\begin{array}{r}0.6786 \\
(8.68)\end{array}$ & $\begin{array}{r}0.6443 \\
(4.02)\end{array}$ & $\begin{array}{l}0.7715 \\
(31.56)\end{array}$ & $\begin{array}{l}0.7870 \\
(11.98)\end{array}$ & $\begin{array}{c}0.7445 \\
(8.44)\end{array}$ & $\begin{array}{c}0.7709 \\
(10.03)\end{array}$ \\
\hline$\gamma+\eta / 2+\theta$ & 0.7986 & 0.8854 & 0.9901 & 0.9502 & 0.9929 & 0.9854 & 0.8423 & 0.8050 & 0.9495 & 0.9942 & 0.9604 & 0.9855 & 0.9388 & 0.8110 & 0.9813 & 0.9338 & 0.9870 & 0.9806 \\
\hline
\end{tabular}


Table 3 -Continued

\begin{tabular}{|c|c|c|c|c|c|c|c|c|c|c|c|c|c|c|c|c|c|c|}
\hline & \multicolumn{6}{|c|}{ Holding period of 3 months } & \multicolumn{6}{|c|}{ Holding period of 6 months } & \multicolumn{6}{|c|}{ Holding period of 12 months } \\
\hline & \multicolumn{2}{|c|}{ Winner } & \multicolumn{2}{|c|}{ Loser } & \multicolumn{2}{|c|}{ Momentum } & \multicolumn{2}{|c|}{ Winner } & \multicolumn{2}{|c|}{ Loser } & \multicolumn{2}{|c|}{ Momentum } & \multicolumn{2}{|c|}{ Winner } & \multicolumn{2}{|c|}{ Loser } & \multicolumn{2}{|c|}{ Momentum } \\
\hline & $\mathrm{MM}$ & FFM & $\mathrm{MM}$ & FFM & $\mathrm{MM}$ & FFM & $\mathrm{MM}$ & FFM & $\mathrm{MM}$ & FFM & $\mathrm{MM}$ & FFM & $\mathrm{MM}$ & FFM & $\mathrm{MM}$ & FFM & $\mathrm{MM}$ & FFM \\
\hline \multicolumn{19}{|c|}{ Panel B: Ranking period of 6 months } \\
\hline$\alpha$ & $\begin{array}{c}0.0238 \\
(2.37)\end{array}$ & $\begin{array}{r}0.0171 \\
(2.95)\end{array}$ & $\begin{array}{r}0.0665 \\
(3.25)\end{array}$ & $\begin{array}{c}0.0124 \\
(2.05)\end{array}$ & $\begin{array}{r}-0.0089 \\
(-1.44)\end{array}$ & $\begin{array}{c}0.0011 \\
(0.19)\end{array}$ & $\begin{array}{r}0.0083 \\
(1.29)\end{array}$ & $\begin{array}{r}0.0120 \\
(3.54)\end{array}$ & $\begin{array}{r}0.0556 \\
(4.21)\end{array}$ & $\begin{array}{r}0.0077 \\
(1.53)\end{array}$ & $\begin{array}{c}0.0053 \\
(0.98)\end{array}$ & $\begin{array}{c}0.0093 \\
(1.73)\end{array}$ & $\begin{array}{r}0.0021 \\
(0.34)\end{array}$ & $\begin{array}{r}0.0147 \\
(3.24)\end{array}$ & $\begin{array}{r}0.0683 \\
(2.86)\end{array}$ & $\begin{array}{r}0.0116 \\
(1.83)\end{array}$ & $\begin{array}{c}-0.0014 \\
(-0.22)\end{array}$ & $\begin{array}{r}-0.0044 \\
(-0.72)\end{array}$ \\
\hline$\beta$ & $\begin{array}{l}0.7121 \\
(18.76)\end{array}$ & $\begin{array}{l}0.9063 \\
(48.31)\end{array}$ & $\begin{array}{l}0.7599 \\
(17.51)\end{array}$ & $\begin{array}{l}1.0016 \\
(23.82)\end{array}$ & $\begin{array}{r}-0.0088 \\
(-0.35)\end{array}$ & $\begin{array}{c}-0.1286 \\
(-3.26)\end{array}$ & $\begin{array}{l}0.6508 \\
(23.41)\end{array}$ & $\begin{array}{l}0.8930 \\
(35.16)\end{array}$ & $\begin{array}{l}0.7179 \\
(15.53)\end{array}$ & $\begin{array}{l}0.9755 \\
(22.16)\end{array}$ & $\begin{array}{r}-0.0357 \\
(-1.11)\end{array}$ & $\begin{array}{r}-0.1303 \\
(-3.55)\end{array}$ & $\begin{array}{l}0.6970 \\
(24.31)\end{array}$ & $\begin{array}{l}0.9290 \\
(30.72)\end{array}$ & $\begin{array}{l}0.6563 \\
(10.99)\end{array}$ & $\begin{array}{l}1.0114 \\
(19.72)\end{array}$ & $\begin{array}{c}0.0297 \\
(0.89)\end{array}$ & $\begin{array}{r}-0.0403 \\
(-1.03)\end{array}$ \\
\hline$s$ & - & $\begin{array}{c}0.7554 \\
(25.08)\end{array}$ & - & $\begin{array}{l}1.0790 \\
(18.44)\end{array}$ & - & $\begin{array}{c}-0.3684 \\
(-6.06)\end{array}$ & - & $\begin{array}{l}0.8613 \\
(25.52)\end{array}$ & - & $\begin{array}{l}1.0353 \\
(19.26)\end{array}$ & - & $\begin{array}{r}-0.2423 \\
(-4.04)\end{array}$ & & $\begin{array}{l}0.8999 \\
(22.71)\end{array}$ & & $\begin{array}{l}1.0516 \\
(18.81)\end{array}$ & - & $\begin{array}{r}-0.1348 \\
(-2.27)\end{array}$ \\
\hline$h$ & - & $\begin{array}{r}0.0351 \\
(0.88)\end{array}$ & - & $\begin{array}{r}0.5217 \\
(5.88)\end{array}$ & - & $\begin{array}{c}-0.5132 \\
(-5.55)\end{array}$ & - & $\begin{array}{r}-0.0762 \\
(-1.16)\end{array}$ & - & $\begin{array}{r}0.6217 \\
(7.07)\end{array}$ & - & $\begin{array}{r}-0.6183 \\
(-7.92)\end{array}$ & & $\begin{array}{r}-0.0099 \\
(-0.14)\end{array}$ & & $\begin{array}{r}0.5414 \\
(5.17)\end{array}$ & - & $\begin{array}{r}-0.4616 \\
(-6.11)\end{array}$ \\
\hline$\delta$ & $\begin{array}{r}-0.6727 \\
(-2.11)\end{array}$ & $\begin{array}{r}-0.8283 \\
(-2.55)\end{array}$ & $\begin{array}{r}-1.6774 \\
(-3.66)\end{array}$ & $\begin{array}{r}-0.8451 \\
(-4.37)\end{array}$ & $\begin{array}{c}0.7616 \\
(5.85)\end{array}$ & $\begin{array}{c}0.4445 \\
(2.56)\end{array}$ & $\begin{array}{r}-0.1124 \\
(-0.51)\end{array}$ & $\begin{array}{r}-0.4970 \\
(-2.43)\end{array}$ & $\begin{array}{r}-1.4994 \\
(-4.74)\end{array}$ & $\begin{array}{r}-0.7812 \\
(-4.48)\end{array}$ & $\begin{array}{c}0.3538 \\
(2.28)\end{array}$ & $\begin{array}{c}0.3369 \\
(2.02)\end{array}$ & $\begin{array}{r}-0.0118 \\
(-0.06)\end{array}$ & $\begin{array}{r}-0.7783 \\
(-2.95)\end{array}$ & $\begin{array}{r}-1.7612 \\
(-3.32)\end{array}$ & $\begin{array}{r}-0.8700 \\
(-3.96)\end{array}$ & $\begin{array}{c}0.4165 \\
(2.28)\end{array}$ & $\begin{array}{c}0.5464 \\
(3.02)\end{array}$ \\
\hline$\omega$ & $\begin{array}{c}0.0003 \\
(3.20)\end{array}$ & $\begin{array}{r}0.0001 \\
(3.40)\end{array}$ & $\begin{array}{r}0.0003 \\
(2.99)\end{array}$ & $\begin{array}{r}0.0000 \\
(1.38)\end{array}$ & $\begin{array}{c}0.0000 \\
(1.74)\end{array}$ & $\begin{array}{c}0.0002 \\
(2.06)\end{array}$ & $\begin{array}{r}0.0003 \\
(2.39)\end{array}$ & $\begin{array}{c}0.0001 \\
(3.29)\end{array}$ & $\begin{array}{r}0.0003 \\
(2.81)\end{array}$ & $\begin{array}{r}0.0000 \\
(1.29)\end{array}$ & $\begin{array}{c}0.0001 \\
(1.31)\end{array}$ & $\begin{array}{c}0.0001 \\
(1.53)\end{array}$ & $\begin{array}{c}0.0001 \\
(2.45)\end{array}$ & $\begin{array}{r}0.0001 \\
(1.76)\end{array}$ & $\begin{array}{r}0.0003 \\
(2.01)\end{array}$ & $\begin{array}{c}0.0001 \\
(1.71)\end{array}$ & $\begin{array}{c}0.0001 \\
(1.53)\end{array}$ & $\begin{array}{c}0.0001 \\
(1.37)\end{array}$ \\
\hline$\gamma$ & $\begin{array}{c}0.3669 \\
(2.66)\end{array}$ & $\begin{array}{r}0.2077 \\
(1.91)\end{array}$ & $\begin{array}{r}-0.0872 \\
(-8.10)\end{array}$ & $\begin{array}{r}0.0337 \\
(1.21)\end{array}$ & $\begin{array}{c}0.6100 \\
(6.11)\end{array}$ & $\begin{array}{c}0.6568 \\
(3.13)\end{array}$ & $\begin{array}{r}0.5312 \\
(2.16)\end{array}$ & $\begin{array}{r}0.3356 \\
(2.34)\end{array}$ & $\begin{array}{r}-0.0775 \\
(-3.69)\end{array}$ & $\begin{array}{r}0.0729 \\
(1.49)\end{array}$ & $\begin{array}{r}0.4646 \\
(2.69)\end{array}$ & $\begin{array}{c}0.4326 \\
(2.61)\end{array}$ & $\begin{array}{r}0.3751 \\
(3.39)\end{array}$ & $\begin{array}{r}0.2097 \\
(1.96)\end{array}$ & $\begin{array}{r}-0.0169 \\
(-0.70)\end{array}$ & $\begin{array}{r}0.0894 \\
(1.62)\end{array}$ & $\begin{array}{c}0.2988 \\
(2.20)\end{array}$ & $\begin{array}{c}0.2407 \\
(2.32)\end{array}$ \\
\hline$\eta$ & $\begin{array}{r}-0.1478 \\
(-0.82)\end{array}$ & $\begin{array}{r}0.2377 \\
(1.26)\end{array}$ & $\begin{array}{r}0.3757 \\
(4.08)\end{array}$ & $\begin{array}{r}0.2300 \\
(3.20)\end{array}$ & $\begin{array}{r}-0.5096 \\
(-5.38)\end{array}$ & $\begin{array}{r}-0.6385 \\
(-3.13)\end{array}$ & $\begin{array}{r}-0.3465 \\
(-1.55)\end{array}$ & $\begin{array}{c}0.1933 \\
(0.78)\end{array}$ & $\begin{array}{r}0.3698 \\
(3.17)\end{array}$ & $\begin{array}{c}0.1661 \\
(2.08)\end{array}$ & $\begin{array}{r}-0.4266 \\
(-2.49)\end{array}$ & $\begin{array}{r}-0.3755 \\
(-2.29)\end{array}$ & $\begin{array}{r}-0.2771 \\
(-2.00)\end{array}$ & $\begin{array}{r}0.2078 \\
(1.01)\end{array}$ & $\begin{array}{r}0.4085 \\
(2.96)\end{array}$ & $\begin{array}{r}0.1604 \\
(1.65)\end{array}$ & $\begin{array}{r}-0.2044 \\
(-1.67)\end{array}$ & $\begin{array}{r}-0.1316 \\
(-1.37)\end{array}$ \\
\hline$\theta$ & $\begin{array}{c}0.4155 \\
(2.34)\end{array}$ & $\begin{array}{r}0.3368 \\
(2.46)\end{array}$ & $\begin{array}{l}0.7780 \\
(10.88)\end{array}$ & $\begin{array}{l}0.8498 \\
(19.40)\end{array}$ & $\begin{array}{l}0.6198 \\
(12.93)\end{array}$ & $\begin{array}{c}0.6158 \\
(5.97)\end{array}$ & $\begin{array}{r}0.4885 \\
(3.47)\end{array}$ & $\begin{array}{r}0.2825 \\
(2.32)\end{array}$ & $\begin{array}{l}0.8030 \\
(13.39)\end{array}$ & $\begin{array}{l}0.8409 \\
(18.17)\end{array}$ & $\begin{array}{r}0.7403 \\
(9.74)\end{array}$ & $\begin{array}{c}0.7534 \\
(9.26)\end{array}$ & $\begin{array}{c}0.6475 \\
(6.63)\end{array}$ & $\begin{array}{c}0.4660 \\
(2.41)\end{array}$ & $\begin{array}{r}0.7060 \\
(6.73)\end{array}$ & $\begin{array}{l}0.8029 \\
(11.64)\end{array}$ & $\begin{array}{c}0.7768 \\
(8.99)\end{array}$ & $\begin{array}{l}0.8062 \\
(11.49)\end{array}$ \\
\hline$\gamma+\eta / 2+\theta$ & 0.7085 & 0.6634 & 0.8787 & 0.9985 & 0.9750 & 0.9533 & 0.8465 & 0.7147 & 0.9105 & 0.9969 & 0.9916 & 0.9983 & 0.8840 & 0.7795 & 0.8933 & 0.9725 & 0.9734 & 0.9811 \\
\hline \multicolumn{19}{|c|}{ Panel C: Ranking period of 12 months } \\
\hline$\alpha$ & $\begin{array}{r}0.0086 \\
(1.35)\end{array}$ & $\begin{array}{r}0.0240 \\
(3.36)\end{array}$ & $\begin{array}{c}0.0683 \\
(3.21)\end{array}$ & $\begin{array}{c}0.0179 \\
(2.72)\end{array}$ & $\begin{array}{r}-0.0103 \\
(-1.58)\end{array}$ & $\begin{array}{r}-0.0085 \\
(-1.31)\end{array}$ & $\begin{array}{c}0.0172 \\
(2.21)\end{array}$ & $\begin{array}{c}0.0171 \\
(4.68)\end{array}$ & $\begin{array}{c}0.0452 \\
(2.29)\end{array}$ & $\begin{array}{c}0.0113 \\
(1.32)\end{array}$ & $\begin{array}{c}0.0093 \\
(1.52)\end{array}$ & $\begin{array}{c}0.0038 \\
(0.52)\end{array}$ & $\begin{array}{c}0.0011 \\
(0.18)\end{array}$ & $\begin{array}{c}0.0150 \\
(2.87)\end{array}$ & $\begin{array}{c}0.0548 \\
(2.52)\end{array}$ & $\begin{array}{c}0.0208 \\
(1.38)\end{array}$ & $\begin{array}{r}-0.0053 \\
(-0.72)\end{array}$ & $\begin{array}{r}-0.0025 \\
(-0.32)\end{array}$ \\
\hline$\beta$ & $\begin{array}{c}0.7515 \\
(26.31)\end{array}$ & $\begin{array}{l}0.9605 \\
(31.43)\end{array}$ & $\begin{array}{c}0.6929 \\
(16.53)\end{array}$ & $\begin{array}{l}0.9120 \\
(18.75)\end{array}$ & $\begin{array}{c}0.1299 \\
(2.38)\end{array}$ & $\begin{array}{c}0.0736 \\
(1.32)\end{array}$ & $\begin{array}{c}0.7431 \\
(16.12)\end{array}$ & $\begin{array}{l}0.9438 \\
(34.33)\end{array}$ & $\begin{array}{l}0.6810 \\
(14.93)\end{array}$ & $\begin{array}{l}0.9959 \\
(29.14)\end{array}$ & $\begin{array}{c}0.0282 \\
(0.68)\end{array}$ & $\begin{array}{r}-0.0366 \\
(-0.85)\end{array}$ & $\begin{array}{l}0.7285 \\
(26.61)\end{array}$ & $\begin{array}{c}0.9593 \\
(69.71)\end{array}$ & $\begin{array}{c}0.6872 \\
(14.87)\end{array}$ & $\begin{array}{l}0.9881 \\
(34.46)\end{array}$ & $\begin{array}{c}0.0902 \\
(2.68)\end{array}$ & $\begin{array}{r}-0.0151 \\
(-0.43)\end{array}$ \\
\hline$s$ & & $\begin{array}{l}0.7941 \\
(18.67)\end{array}$ & - & $\begin{array}{l}0.8258 \\
(15.29)\end{array}$ & - & $\begin{array}{r}-0.0873 \\
(-1.19)\end{array}$ & - & $\begin{array}{l}0.8290 \\
(22.31)\end{array}$ & - & $\begin{array}{c}1.0513 \\
(19.40)\end{array}$ & - & $\begin{array}{r}-0.2256 \\
(-3.64)\end{array}$ & & $\begin{array}{c}0.8769 \\
(35.00)\end{array}$ & & $\begin{array}{l}1.0448 \\
(20.56)\end{array}$ & - & $\begin{array}{r}-0.1735 \\
(-3.12)\end{array}$ \\
\hline$h$ & & $\begin{array}{r}-0.0816 \\
(-0.95)\end{array}$ & - & $\begin{array}{c}0.5744 \\
(8.25)\end{array}$ & - & $\begin{array}{c}-0.5398 \\
(-4.68)\end{array}$ & - & $\begin{array}{r}-0.0317 \\
(-0.55)\end{array}$ & - & $\begin{array}{c}0.6272 \\
(9.70)\end{array}$ & - & $\begin{array}{r}-0.7148 \\
(-9.42)\end{array}$ & & $\begin{array}{r}0.0108 \\
(0.31)\end{array}$ & & $\begin{array}{l}0.6901 \\
(11.33)\end{array}$ & - & $\begin{array}{r}-0.6555 \\
(-8.74)\end{array}$ \\
\hline$\delta$ & $\begin{array}{r}-0.1314 \\
(-0.56)\end{array}$ & $\begin{array}{r}-1.0132 \\
(-3.14)\end{array}$ & $\begin{array}{r}-1.8889 \\
(-3.56)\end{array}$ & $\begin{array}{r}-0.9683 \\
(-4.45)\end{array}$ & $\begin{array}{c}0.5879 \\
(3.72)\end{array}$ & $\begin{array}{c}0.6233 \\
(3.23)\end{array}$ & $\begin{array}{r}-0.3595 \\
(-1.43)\end{array}$ & $\begin{array}{r}-0.6839 \\
(-3.58)\end{array}$ & $\begin{array}{r}-1.2735 \\
(-2.99)\end{array}$ & $\begin{array}{r}-0.8920 \\
(-3.10)\end{array}$ & $\begin{array}{c}0.2718 \\
(1.64)\end{array}$ & $\begin{array}{c}0.4790 \\
(2.36)\end{array}$ & $\begin{array}{r}0.0539 \\
(0.25)\end{array}$ & $\begin{array}{c}-0.7640 \\
(-2.33)\end{array}$ & $\begin{array}{c}-1.4360 \\
(-2.79)\end{array}$ & $\begin{array}{r}-1.1617 \\
(-2.26)\end{array}$ & $\begin{array}{c}0.5327 \\
(2.64)\end{array}$ & $\begin{array}{c}0.5535 \\
(2.35)\end{array}$ \\
\hline$\omega$ & $\begin{array}{r}0.0001 \\
(2.25)\end{array}$ & $\begin{array}{r}0.0001 \\
(2.42)\end{array}$ & $\begin{array}{r}0.0003 \\
(2.30)\end{array}$ & $\begin{array}{r}0.0000 \\
(1.58)\end{array}$ & $\begin{array}{c}0.0001 \\
(1.77)\end{array}$ & $\begin{array}{c}0.0000 \\
(1.15)\end{array}$ & $\begin{array}{r}0.0003 \\
(1.72)\end{array}$ & $\begin{array}{r}0.0001 \\
(2.44)\end{array}$ & $\begin{array}{r}0.0001 \\
(1.80)\end{array}$ & $\begin{array}{c}0.0001 \\
(1.43)\end{array}$ & $\begin{array}{c}0.0000 \\
(0.94)\end{array}$ & $\begin{array}{c}0.0001 \\
(1.22)\end{array}$ & $\begin{array}{r}0.0001 \\
(2.12)\end{array}$ & $\begin{array}{r}0.0001 \\
(3.79)\end{array}$ & $\begin{array}{r}0.0005 \\
(2.78)\end{array}$ & $\begin{array}{r}0.0002 \\
(2.29)\end{array}$ & $\begin{array}{c}0.0001 \\
(1.26)\end{array}$ & $\begin{array}{c}0.0001 \\
(1.90)\end{array}$ \\
\hline$\gamma$ & $\begin{array}{c}0.2372 \\
(2.57)\end{array}$ & $\begin{array}{r}0.2298 \\
(2.39)\end{array}$ & $\begin{array}{r}-0.0634 \\
(-3.75)\end{array}$ & $\begin{array}{r}0.0150 \\
(0.41)\end{array}$ & $\begin{array}{r}0.4103 \\
(4.24)\end{array}$ & $\begin{array}{c}0.2702 \\
(4.00)\end{array}$ & $\begin{array}{r}0.2945 \\
(2.48)\end{array}$ & $\begin{array}{r}0.2168 \\
(1.78)\end{array}$ & $\begin{array}{r}-0.0269 \\
(-1.88)\end{array}$ & $\begin{array}{c}-0.0081 \\
(-0.31)\end{array}$ & $\begin{array}{c}0.3080 \\
(2.45)\end{array}$ & $\begin{array}{r}0.2646 \\
(2.60)\end{array}$ & $\begin{array}{c}0.2193 \\
(3.15)\end{array}$ & $\begin{array}{r}0.0907 \\
(1.51)\end{array}$ & $\begin{array}{r}-0.0318 \\
(-1.53)\end{array}$ & $\begin{array}{r}0.0339 \\
(1.09)\end{array}$ & $\begin{array}{c}0.2863 \\
(2.33)\end{array}$ & $\begin{array}{c}0.2002 \\
(2.17)\end{array}$ \\
\hline$\eta$ & $\begin{array}{r}-0.2343 \\
(-1.89)\end{array}$ & $\begin{array}{r}-0.0053 \\
(-0.04)\end{array}$ & $\begin{array}{r}0.3392 \\
(3.50)\end{array}$ & $\begin{array}{r}0.2111 \\
(2.92)\end{array}$ & $\begin{array}{r}-0.3914 \\
(-3.06)\end{array}$ & $\begin{array}{r}-0.3132 \\
(-2.58)\end{array}$ & $\begin{array}{r}-0.0585 \\
(-0.39)\end{array}$ & $\begin{array}{r}0.2030 \\
(0.92)\end{array}$ & $\begin{array}{r}0.1757 \\
(2.12)\end{array}$ & $\begin{array}{c}0.2346 \\
(2.65)\end{array}$ & $\begin{array}{r}-0.2691 \\
(-2.25)\end{array}$ & $\begin{array}{r}-0.1370 \\
(-1.46)\end{array}$ & $\begin{array}{r}-0.1521 \\
(-2.36)\end{array}$ & $\begin{array}{r}0.2957 \\
(2.43)\end{array}$ & $\begin{array}{r}0.3299 \\
(2.32)\end{array}$ & $\begin{array}{c}0.1980 \\
(2.42)\end{array}$ & $\begin{array}{r}-0.2352 \\
(-2.03)\end{array}$ & $\begin{array}{r}-0.0478 \\
(-0.53)\end{array}$ \\
\hline$\theta$ & $\begin{array}{c}0.7386 \\
(8.51)\end{array}$ & $\begin{array}{r}0.5574 \\
(3.74)\end{array}$ & $\begin{array}{r}0.7608 \\
(8.13)\end{array}$ & $\begin{array}{l}0.8732 \\
(21.44)\end{array}$ & $\begin{array}{l}0.7772 \\
(14.61)\end{array}$ & $\begin{array}{l}0.8642 \\
(23.23)\end{array}$ & $\begin{array}{r}0.5113 \\
(2.58)\end{array}$ & $\begin{array}{r}0.5054 \\
(3.66)\end{array}$ & $\begin{array}{l}0.9130 \\
(18.37)\end{array}$ & $\begin{array}{l}0.8770 \\
(16.64)\end{array}$ & $\begin{array}{l}0.7880 \\
(12.77)\end{array}$ & $\begin{array}{l}0.7816 \\
(10.95)\end{array}$ & $\begin{array}{c}0.7083 \\
(6.09)\end{array}$ & $\begin{array}{r}0.5904 \\
(9.69)\end{array}$ & $\begin{array}{r}0.6777 \\
(7.22)\end{array}$ & $\begin{array}{r}0.7013 \\
(7.30)\end{array}$ & $\begin{array}{l}0.8298 \\
(12.26)\end{array}$ & $\begin{array}{c}0.7385 \\
(8.86)\end{array}$ \\
\hline$\gamma+\eta / 2+\theta$ & 0.8587 & 0.7845 & 0.8671 & 0.9937 & 0.9918 & 0.9778 & 0.7766 & 0.8238 & 0.9739 & 0.9862 & 0.9614 & 0.9777 & 0.8515 & 0.8290 & 0.8108 & 0.8343 & 0.9985 & 0.9148 \\
\hline
\end{tabular}




\section{Table 4 - Conditional market and Fama and French models with a GARCH $(1,1)$-M term}

The table reports coefficient estimates for systems (5) and (6) for the winner, loser and momentum portfolios. Winner (Loser) is an equallyweighted non-overlapping portfolio containing the $10 \%$ of stocks that performed the best (worst) over a given ranking period. Momentum is a portfolio that buys the winner portfolio and short sells the loser portfolio. $\alpha$ measures the portfolio's abnormal performance, $\beta$ measures the market risk, $s$ and $h$ are the portfolio loadings on the size and book-to-market value factors as measured by Fama and French (1993), $\delta \sigma_{t}$ is the time-varying risk exposure. The conditional variance of the portfolio returns follows a GARCH(1,1) structure as $\sigma_{t}^{2}=\omega+\gamma \varepsilon_{t-1}^{2}+\theta \sigma_{t-1}^{2}$, where $\omega, \gamma$ and $\theta$ are parameters. MM refers to the market model and FFM refers to the Fama and French model. Bollerslev-Wooldridge robust $t$-statistics are in parentheses.

\begin{tabular}{|c|c|c|c|c|c|c|c|c|c|c|c|c|c|c|c|c|c|c|}
\hline & \multicolumn{6}{|c|}{ Holding period of 3 months } & \multicolumn{6}{|c|}{ Holding period of 6 months } & \multicolumn{6}{|c|}{ Holding period of 12 months } \\
\hline & \multicolumn{2}{|c|}{ Winner } & \multicolumn{2}{|c|}{ Loser } & \multicolumn{2}{|c|}{ Momentum } & \multicolumn{2}{|c|}{ Winner } & \multicolumn{2}{|c|}{ Loser } & \multicolumn{2}{|c|}{ Momentum } & \multicolumn{2}{|c|}{ Winner } & \multicolumn{2}{|c|}{ Loser } & \multicolumn{2}{|c|}{ Momentum } \\
\hline & $\mathrm{MM}$ & FFM & $\mathrm{MM}$ & FFM & $\mathrm{MM}$ & $\mathrm{FFM}$ & $\mathrm{MM}$ & FFM & $\mathrm{MM}$ & FFM & $\mathrm{MM}$ & FFM & $\mathrm{MM}$ & FFM & $\mathrm{MM}$ & FFM & $\mathrm{MM}$ & FFM \\
\hline \multicolumn{19}{|c|}{ Panel A: Ranking period of 3 months } \\
\hline$\alpha$ & $\begin{array}{c}0.0172 \\
(1.75)\end{array}$ & $\begin{array}{r}0.0163 \\
(2.53)\end{array}$ & $\begin{array}{r}-0.0150 \\
(-2.38)\end{array}$ & $\begin{array}{r}0.0031 \\
(0.60)\end{array}$ & $\begin{array}{r}0.0109 \\
(1.57)\end{array}$ & $\begin{array}{r}0.0092 \\
(1.25)\end{array}$ & $\begin{array}{c}0.0130 \\
(2.22)\end{array}$ & $\begin{array}{r}0.0078 \\
(2.05)\end{array}$ & $\begin{array}{r}-0.0071 \\
(-1.05)\end{array}$ & $\begin{array}{r}0.0032 \\
(0.79)\end{array}$ & $\begin{array}{r}0.0067 \\
(1.09)\end{array}$ & $\begin{array}{r}0.0067 \\
(1.24)\end{array}$ & $\begin{array}{r}0.0035 \\
(0.58)\end{array}$ & $\begin{array}{r}0.0153 \\
(2.12)\end{array}$ & $\begin{array}{r}-0.0071 \\
(-1.09)\end{array}$ & $\begin{array}{r}0.0012 \\
(0.24)\end{array}$ & $\begin{array}{r}0.0077 \\
(1.54)\end{array}$ & $\begin{array}{r}0.0064 \\
(1.14)\end{array}$ \\
\hline$\beta$ & $\begin{array}{l}0.7171 \\
(16.67)\end{array}$ & $\begin{array}{l}0.9410 \\
(34.45)\end{array}$ & $\begin{array}{l}0.7700 \\
(15.46)\end{array}$ & $\begin{array}{l}1.0342 \\
(18.26)\end{array}$ & $\begin{array}{r}-0.0558 \\
(-1.41)\end{array}$ & $\begin{array}{r}-0.1376 \\
(-3.23)\end{array}$ & $\begin{array}{c}0.6950 \\
(18.43)\end{array}$ & $\begin{array}{l}0.8734 \\
(28.30)\end{array}$ & $\begin{array}{l}0.7387 \\
(15.22)\end{array}$ & $\begin{array}{l}1.0441 \\
(27.21)\end{array}$ & $\begin{array}{r}-0.0749 \\
(-1.93)\end{array}$ & $\begin{array}{r}-0.1802 \\
(-4.25)\end{array}$ & $\begin{array}{l}0.7355 \\
(24.39)\end{array}$ & $\begin{array}{l}0.9907 \\
(50.51)\end{array}$ & $\begin{array}{l}0.6657 \\
(13.54)\end{array}$ & $\begin{array}{l}0.9779 \\
(33.22)\end{array}$ & $\begin{array}{r}0.0668 \\
(2.07)\end{array}$ & $\begin{array}{r}0.0166 \\
(0.51)\end{array}$ \\
\hline$s$ & - & $\begin{array}{c}0.8956 \\
(21.94)\end{array}$ & - & $\begin{array}{c}1.0596 \\
(17.66)\end{array}$ & - & $\begin{array}{r}-0.2162 \\
(-3.27)\end{array}$ & - & $\begin{array}{l}0.8078 \\
(21.28)\end{array}$ & - & $\begin{array}{c}1.0992 \\
(24.30)\end{array}$ & - & $\begin{array}{r}-0.2886 \\
(-4.85)\end{array}$ & & $\begin{array}{l}0.8964 \\
(27.37)\end{array}$ & - & $\begin{array}{l}1.0494 \\
(22.95)\end{array}$ & - & $\begin{array}{r}-0.1385 \\
(-2.51)\end{array}$ \\
\hline$h$ & - & $\begin{array}{c}0.0685 \\
(1.10)\end{array}$ & - & $\begin{array}{r}0.3909 \\
(4.60)\end{array}$ & - & $\begin{array}{r}-0.3291 \\
(-3.86)\end{array}$ & - & $\begin{array}{c}0.1073 \\
(2.16)\end{array}$ & - & $\begin{array}{r}0.5567 \\
(7.56)\end{array}$ & - & $\begin{array}{r}-0.5041 \\
(-6.07)\end{array}$ & & $\begin{array}{r}0.1340 \\
(2.90)\end{array}$ & - & $\begin{array}{c}0.4895 \\
(9.58)\end{array}$ & - & $\begin{array}{r}-0.3182 \\
(-4.59)\end{array}$ \\
\hline$\delta$ & $\begin{array}{r}-0.5803 \\
(-1.94)\end{array}$ & $\begin{array}{r}-0.9597 \\
(-2.78)\end{array}$ & $\begin{array}{r}0.1459 \\
(1.01)\end{array}$ & $\begin{array}{r}-0.3789 \\
(-2.28)\end{array}$ & $\begin{array}{r}-0.0829 \\
(-0.43)\end{array}$ & $\begin{array}{r}-0.0042 \\
(-0.02)\end{array}$ & $\begin{array}{r}-0.3731 \\
(-2.06)\end{array}$ & $\begin{array}{r}-0.4330 \\
(-2.04)\end{array}$ & $\begin{array}{r}-0.0298 \\
(-0.20)\end{array}$ & $\begin{array}{r}-0.4875 \\
(-3.31)\end{array}$ & $\begin{array}{r}0.1000 \\
(0.58)\end{array}$ & $\begin{array}{r}0.1825 \\
(1.10)\end{array}$ & $\begin{array}{r}-0.1001 \\
(-0.52)\end{array}$ & $\begin{array}{r}-0.7551 \\
(-2.12)\end{array}$ & $\begin{array}{r}-0.0524 \\
(-0.34)\end{array}$ & $\begin{array}{r}-0.4790 \\
(-2.32)\end{array}$ & $\begin{array}{r}0.0989 \\
(0.60)\end{array}$ & $\begin{array}{r}0.1898 \\
(1.02)\end{array}$ \\
\hline$\omega$ & $\begin{array}{r}0.0003 \\
(2.85)\end{array}$ & $\begin{array}{c}0.0001 \\
(2.56)\end{array}$ & $\begin{array}{r}0.0001 \\
(1.16)\end{array}$ & $\begin{array}{c}0.0001 \\
(1.39)\end{array}$ & $\begin{array}{r}0.0002 \\
(1.87)\end{array}$ & $\begin{array}{r}0.0001 \\
(1.66)\end{array}$ & $\begin{array}{r}0.0003 \\
(3.39)\end{array}$ & $\begin{array}{c}0.0001 \\
(3.78)\end{array}$ & $\begin{array}{c}0.0001 \\
(0.98)\end{array}$ & $\begin{array}{c}0.0001 \\
(1.42)\end{array}$ & $\begin{array}{c}0.0001 \\
(2.10)\end{array}$ & $\begin{array}{r}0.0001 \\
(1.89)\end{array}$ & $\begin{array}{r}0.0001 \\
(2.14)\end{array}$ & $\begin{array}{c}0.0001 \\
(2.76)\end{array}$ & $\begin{array}{r}0.0001 \\
(1.49)\end{array}$ & $\begin{array}{r}0.0000 \\
(1.47)\end{array}$ & $\begin{array}{r}0.0001 \\
(1.60)\end{array}$ & $\begin{array}{r}0.0001 \\
(1.48)\end{array}$ \\
\hline$\gamma$ & $\begin{array}{r}0.2416 \\
(2.85)\end{array}$ & $\begin{array}{r}0.1568 \\
(2.96)\end{array}$ & $\begin{array}{r}0.1818 \\
(3.27)\end{array}$ & $\begin{array}{r}0.2060 \\
(3.22)\end{array}$ & $\begin{array}{r}0.2466 \\
(2.63)\end{array}$ & $\begin{array}{r}0.2103 \\
(2.59)\end{array}$ & $\begin{array}{r}0.3767 \\
(3.53)\end{array}$ & $\begin{array}{r}0.3992 \\
(2.45)\end{array}$ & $\begin{array}{r}0.1676 \\
(2.84)\end{array}$ & $\begin{array}{r}0.2590 \\
(3.66)\end{array}$ & $\begin{array}{r}0.2758 \\
(3.20)\end{array}$ & $\begin{array}{r}0.2870 \\
(3.16)\end{array}$ & $\begin{array}{r}0.2742 \\
(2.88)\end{array}$ & $\begin{array}{r}0.2050 \\
(2.36)\end{array}$ & $\begin{array}{c}0.2603 \\
(2.00)\end{array}$ & $\begin{array}{r}0.2237 \\
(3.85)\end{array}$ & $\begin{array}{r}0.2395 \\
(2.94)\end{array}$ & $\begin{array}{r}0.1949 \\
(3.09)\end{array}$ \\
\hline$\theta$ & $\begin{array}{c}0.4927 \\
(3.83)\end{array}$ & $\begin{array}{l}0.7286 \\
(11.22)\end{array}$ & $\begin{array}{c}0.8114 \\
(13.71)\end{array}$ & $\begin{array}{r}0.7609 \\
(9.48)\end{array}$ & $\begin{array}{c}0.7012 \\
(7.05)\end{array}$ & $\begin{array}{r}0.7349 \\
(7.85)\end{array}$ & $\begin{array}{r}0.4405 \\
(4.77)\end{array}$ & $\begin{array}{c}0.3723 \\
(3.36)\end{array}$ & $\begin{array}{l}0.8274 \\
(12.73)\end{array}$ & $\begin{array}{l}0.7265 \\
(10.47)\end{array}$ & $\begin{array}{c}0.7079 \\
(9.00)\end{array}$ & $\begin{array}{r}0.7033 \\
(8.05)\end{array}$ & $\begin{array}{c}0.6642 \\
(8.76)\end{array}$ & $\begin{array}{r}0.5263 \\
(5.09)\end{array}$ & $\begin{array}{r}0.7110 \\
(5.70)\end{array}$ & $\begin{array}{l}0.7642 \\
(13.63)\end{array}$ & $\begin{array}{r}0.7327 \\
(8.37)\end{array}$ & $\begin{array}{c}0.7772 \\
(10.42)\end{array}$ \\
\hline$\gamma+\theta$ & 0.7342 & 0.8854 & 0.9932 & 0.9669 & 0.9478 & 0.9452 & 0.8172 & 0.7715 & 0.9950 & 0.9855 & 0.9837 & 0.9903 & 0.9384 & 0.7313 & 0.9713 & 0.9879 & 0.9722 & 0.9721 \\
\hline
\end{tabular}


Table 4 - Continued

\begin{tabular}{|c|c|c|c|c|c|c|c|c|c|c|c|c|c|c|c|c|c|c|}
\hline & \multicolumn{6}{|c|}{ Holding period of 3 months } & \multicolumn{6}{|c|}{ Holding period of 6 months } & \multicolumn{6}{|c|}{ Holding period of 12 months } \\
\hline & \multicolumn{2}{|c|}{ Winner } & \multicolumn{2}{|c|}{ Loser } & \multicolumn{2}{|c|}{ Momentum } & \multicolumn{2}{|c|}{ Winner } & \multicolumn{2}{|c|}{ Loser } & \multicolumn{2}{|c|}{ Momentum } & \multicolumn{2}{|c|}{ Winner } & \multicolumn{2}{|c|}{ Loser } & \multicolumn{2}{|c|}{ Momentum } \\
\hline & $\mathrm{MM}$ & FFM & $\mathrm{MM}$ & FFM & $\mathrm{MM}$ & FFM & $\mathrm{MM}$ & FFM & $\mathrm{MM}$ & FFM & $\mathrm{MM}$ & FFM & $\mathrm{MM}$ & FFM & $\mathrm{MM}$ & $\mathrm{FFM}$ & $\mathrm{MM}$ & FFM \\
\hline \multicolumn{19}{|c|}{ Panel B: Ranking period of 6 months } \\
\hline$\alpha$ & $\begin{array}{r}0.0283 \\
(2.18)\end{array}$ & $\begin{array}{r}0.0150 \\
(2.91)\end{array}$ & $\begin{array}{r}-0.0150 \\
(-2.37)\end{array}$ & $\begin{array}{r}0.0021 \\
(0.41)\end{array}$ & $\begin{array}{r}0.0213 \\
(3.61)\end{array}$ & $\begin{array}{r}0.0165 \\
(2.65)\end{array}$ & $\begin{array}{r}0.0190 \\
(2.52)\end{array}$ & $\begin{array}{r}0.0108 \\
(3.12)\end{array}$ & $\begin{array}{r}-0.0114 \\
(-1.67)\end{array}$ & $\begin{array}{r}0.0057 \\
(1.15)\end{array}$ & $\begin{array}{r}0.0186 \\
(3.14)\end{array}$ & $\begin{array}{r}0.0181 \\
(3.13)\end{array}$ & $\begin{array}{c}0.0091 \\
(1.71)\end{array}$ & $\begin{array}{r}0.0138 \\
(3.31)\end{array}$ & $\begin{array}{r}-0.0128 \\
(-1.81)\end{array}$ & $\begin{array}{r}0.0045 \\
(0.89)\end{array}$ & $\begin{array}{c}0.0081 \\
(1.40)\end{array}$ & $\begin{array}{r}-0.0003 \\
(-0.05)\end{array}$ \\
\hline$\beta$ & $\begin{array}{l}0.7224 \\
(18.86)\end{array}$ & $\begin{array}{l}0.8992 \\
(47.75)\end{array}$ & $\begin{array}{l}0.7192 \\
(14.72)\end{array}$ & $\begin{array}{l}1.0109 \\
(23.67)\end{array}$ & $\begin{array}{r}-0.0117 \\
(-0.30)\end{array}$ & $\begin{array}{r}-0.1313 \\
(-3.31)\end{array}$ & $\begin{array}{l}0.6980 \\
(16.12)\end{array}$ & $\begin{array}{l}0.8930 \\
(34.37)\end{array}$ & $\begin{array}{l}0.7153 \\
(14.33)\end{array}$ & $\begin{array}{l}0.9828 \\
(24.88)\end{array}$ & $\begin{array}{r}-0.0419 \\
(-1.10)\end{array}$ & $\begin{array}{r}-0.1289 \\
(-3.45)\end{array}$ & $\begin{array}{l}0.7323 \\
(18.46)\end{array}$ & $\begin{array}{l}0.9255 \\
(31.52)\end{array}$ & $\begin{array}{l}0.7129 \\
(16.18)\end{array}$ & $\begin{array}{l}1.0051 \\
(21.22)\end{array}$ & $\begin{array}{r}0.0254 \\
(0.77)\end{array}$ & $\begin{array}{r}-0.0387 \\
(-1.00)\end{array}$ \\
\hline$s$ & - & $\begin{array}{l}0.7512 \\
(24.65)\end{array}$ & - & $\begin{array}{l}1.0820 \\
(18.29)\end{array}$ & - & $\begin{array}{r}-0.3124 \\
(-4.68)\end{array}$ & - & $\begin{array}{l}0.8611 \\
(27.49)\end{array}$ & - & $\begin{array}{l}1.0449 \\
(20.01)\end{array}$ & - & $\begin{array}{r}-0.2304 \\
(-4.03)\end{array}$ & - & $\begin{array}{l}0.9008 \\
(23.45)\end{array}$ & - & $\begin{array}{l}1.0502 \\
(18.88)\end{array}$ & - & $\begin{array}{r}-0.1232 \\
(-2.13)\end{array}$ \\
\hline$h$ & - & $\begin{array}{r}0.0432 \\
(1.06)\end{array}$ & - & $\begin{array}{r}0.5991 \\
(6.33)\end{array}$ & - & $\begin{array}{r}-0.6037 \\
(-7.10)\end{array}$ & - & $\begin{array}{r}-0.0709 \\
(-1.07)\end{array}$ & - & $\begin{array}{c}0.6771 \\
(8.10)\end{array}$ & - & $\begin{array}{r}-0.6706 \\
(-8.58)\end{array}$ & - & $\begin{array}{r}0.0039 \\
(0.06)\end{array}$ & - & $\begin{array}{r}0.5533 \\
(6.14)\end{array}$ & - & $\begin{array}{r}-0.5045 \\
(-7.15)\end{array}$ \\
\hline$\delta$ & $\begin{array}{r}-0.8193 \\
(-2.04)\end{array}$ & $\begin{array}{r}-0.7123 \\
(-2.44)\end{array}$ & $\begin{array}{r}0.1034 \\
(0.76)\end{array}$ & $\begin{array}{r}-0.4411 \\
(-2.64)\end{array}$ & $\begin{array}{r}-0.1711 \\
(-1.10)\end{array}$ & $\begin{array}{r}-0.0009 \\
(-0.01)\end{array}$ & $\begin{array}{r}-0.4831 \\
(-2.08)\end{array}$ & $\begin{array}{r}-0.4164 \\
(-2.01)\end{array}$ & $\begin{array}{r}0.0056 \\
(0.04)\end{array}$ & $\begin{array}{r}-0.6419 \\
(-3.82)\end{array}$ & $\begin{array}{r}-0.0413 \\
(-0.25)\end{array}$ & $\begin{array}{r}0.0528 \\
(0.31)\end{array}$ & $\begin{array}{r}-0.2518 \\
(-1.49)\end{array}$ & $\begin{array}{r}-0.7034 \\
(-2.91)\end{array}$ & $\begin{array}{r}0.0394 \\
(0.25)\end{array}$ & $\begin{array}{r}-0.5709 \\
(-3.32)\end{array}$ & $\begin{array}{r}0.1384 \\
(0.84)\end{array}$ & $\begin{array}{r}0.4128 \\
(2.39)\end{array}$ \\
\hline$\omega$ & $\begin{array}{r}0.0004 \\
(2.72)\end{array}$ & $\begin{array}{r}0.0001 \\
(3.16)\end{array}$ & $\begin{array}{c}0.0001 \\
(1.41)\end{array}$ & $\begin{array}{r}0.0000 \\
(1.39)\end{array}$ & $\begin{array}{r}0.0002 \\
(1.87)\end{array}$ & $\begin{array}{r}0.0002 \\
(1.74)\end{array}$ & $\begin{array}{r}0.0004 \\
(2.62)\end{array}$ & $\begin{array}{c}0.0001 \\
(2.98)\end{array}$ & $\begin{array}{c}0.0001 \\
(1.01)\end{array}$ & $\begin{array}{r}0.0000 \\
(1.20)\end{array}$ & $\begin{array}{r}0.0002 \\
(1.99)\end{array}$ & $\begin{array}{c}0.0001 \\
(1.93)\end{array}$ & $\begin{array}{r}0.0002 \\
(2.37)\end{array}$ & $\begin{array}{c}0.0001 \\
(1.82)\end{array}$ & $\begin{array}{c}0.0001 \\
(1.27)\end{array}$ & $\begin{array}{r}0.0000 \\
(1.64)\end{array}$ & $\begin{array}{c}0.0001 \\
(1.69)\end{array}$ & $\begin{array}{r}0.0001 \\
(1.45)\end{array}$ \\
\hline$\gamma$ & $\begin{array}{c}0.2899 \\
(2.07)\end{array}$ & $\begin{array}{r}0.3016 \\
(2.38)\end{array}$ & $\begin{array}{r}0.2145 \\
(3.52)\end{array}$ & $\begin{array}{r}0.1829 \\
(3.61)\end{array}$ & $\begin{array}{r}0.3538 \\
(2.74)\end{array}$ & $\begin{array}{r}0.2935 \\
(2.92)\end{array}$ & $\begin{array}{r}0.3046 \\
(2.72)\end{array}$ & $\begin{array}{r}0.4324 \\
(3.40)\end{array}$ & $\begin{array}{r}0.1681 \\
(3.27)\end{array}$ & $\begin{array}{r}0.1718 \\
(3.26)\end{array}$ & $\begin{array}{r}0.3023 \\
(2.68)\end{array}$ & $\begin{array}{r}0.2729 \\
(2.89)\end{array}$ & $\begin{array}{r}0.3081 \\
(3.14)\end{array}$ & $\begin{array}{r}0.3285 \\
(2.50)\end{array}$ & $\begin{array}{r}0.1907 \\
(2.39)\end{array}$ & $\begin{array}{r}0.1914 \\
(3.15)\end{array}$ & $\begin{array}{r}0.2142 \\
(2.59)\end{array}$ & $\begin{array}{r}0.1774 \\
(2.86)\end{array}$ \\
\hline$\theta$ & $\begin{array}{r}0.3836 \\
(2.32)\end{array}$ & $\begin{array}{r}0.4132 \\
(3.20)\end{array}$ & $\begin{array}{l}0.7716 \\
(12.04)\end{array}$ & $\begin{array}{l}0.7975 \\
(14.11)\end{array}$ & $\begin{array}{r}0.6171 \\
(5.13)\end{array}$ & $\begin{array}{r}0.6523 \\
(6.42)\end{array}$ & $\begin{array}{r}0.3984 \\
(2.91)\end{array}$ & $\begin{array}{r}0.2998 \\
(2.24)\end{array}$ & $\begin{array}{l}0.8216 \\
(12.87)\end{array}$ & $\begin{array}{l}0.8234 \\
(16.19)\end{array}$ & $\begin{array}{r}0.6607 \\
(6.32)\end{array}$ & $\begin{array}{r}0.6804 \\
(7.48)\end{array}$ & $\begin{array}{r}0.5673 \\
(5.07)\end{array}$ & $\begin{array}{r}0.4610 \\
(2.50)\end{array}$ & $\begin{array}{r}0.7868 \\
(8.92)\end{array}$ & $\begin{array}{l}0.7920 \\
(13.79)\end{array}$ & $\begin{array}{r}0.7440 \\
(8.35)\end{array}$ & $\begin{array}{l}0.7942 \\
(11.28)\end{array}$ \\
\hline$\gamma+\theta$ & 0.6735 & 0.7148 & 0.9861 & 0.9803 & 0.9709 & 0.9458 & 0.7030 & 0.7322 & 0.9897 & 0.9952 & 0.9630 & 0.9533 & 0.8754 & 0.7895 & 0.9776 & 0.9834 & 0.9582 & 0.9716 \\
\hline \multicolumn{19}{|c|}{ Panel C: Ranking period of 12 months } \\
\hline$\alpha$ & $\begin{array}{c}0.0188 \\
(2.48)\end{array}$ & $\begin{array}{c}0.0240 \\
(3.27)\end{array}$ & $\begin{array}{r}-0.0033 \\
(-0.55)\end{array}$ & $\begin{array}{r}0.0097 \\
(1.21)\end{array}$ & $\begin{array}{c}0.0043 \\
(1.09)\end{array}$ & $\begin{array}{r}-0.0038 \\
(-0.55)\end{array}$ & $\begin{array}{r}0.0194 \\
(2.47)\end{array}$ & $\begin{array}{r}0.0174 \\
(4.56)\end{array}$ & $\begin{array}{r}-0.0204 \\
(-2.58)\end{array}$ & $\begin{array}{r}-0.0004 \\
(-0.09)\end{array}$ & $\begin{array}{r}0.0258 \\
(4.01)\end{array}$ & $\begin{array}{r}0.0190 \\
(3.31)\end{array}$ & $\begin{array}{c}0.0081 \\
(1.27)\end{array}$ & $\begin{array}{r}0.0142 \\
(3.62)\end{array}$ & $\begin{array}{r}-0.0175 \\
(-1.97)\end{array}$ & $\begin{array}{r}0.0022 \\
(0.38)\end{array}$ & $\begin{array}{r}0.0090 \\
(1.33)\end{array}$ & $\begin{array}{r}-0.0005 \\
(-0.07)\end{array}$ \\
\hline$\beta$ & $\begin{array}{l}0.7668 \\
(18.82)\end{array}$ & $\begin{array}{l}0.9608 \\
(30.94)\end{array}$ & $\begin{array}{l}0.7292 \\
(13.73)\end{array}$ & $\begin{array}{l}0.9202 \\
(28.97)\end{array}$ & $\begin{array}{r}0.0817 \\
(1.66)\end{array}$ & $\begin{array}{r}0.0590 \\
(1.36)\end{array}$ & $\begin{array}{l}0.7456 \\
(15.96)\end{array}$ & $\begin{array}{l}0.9422 \\
(33.91)\end{array}$ & $\begin{array}{l}0.7036 \\
(13.72)\end{array}$ & $\begin{array}{l}0.9677 \\
(21.57)\end{array}$ & $\begin{array}{r}0.0068 \\
(0.16)\end{array}$ & $\begin{array}{r}-0.0337 \\
(-0.89)\end{array}$ & $\begin{array}{l}0.7682 \\
(17.96)\end{array}$ & $\begin{array}{l}0.9475 \\
(27.76)\end{array}$ & $\begin{array}{l}0.7211 \\
(14.16)\end{array}$ & $\begin{array}{l}1.0180 \\
(21.96)\end{array}$ & $\begin{array}{r}0.0714 \\
(2.01)\end{array}$ & $\begin{array}{r}-0.0255 \\
(-0.71)\end{array}$ \\
\hline$s$ & - & $\begin{array}{l}0.7943 \\
(18.70)\end{array}$ & - & $\begin{array}{l}0.8104 \\
(15.46)\end{array}$ & - & $\begin{array}{r}-0.0637 \\
(-0.96)\end{array}$ & - & $\begin{array}{l}0.8215 \\
(23.06)\end{array}$ & - & $\begin{array}{l}1.0589 \\
(16.87)\end{array}$ & - & $\begin{array}{r}-0.1675 \\
(-3.09)\end{array}$ & - & $\begin{array}{l}0.8626 \\
(25.63)\end{array}$ & - & $\begin{array}{l}1.0649 \\
(17.37)\end{array}$ & - & $\begin{array}{r}-0.1756 \\
(-3.27)\end{array}$ \\
\hline$h$ & - & $\begin{array}{r}-0.0819 \\
(-0.95)\end{array}$ & - & $\begin{array}{r}0.6079 \\
(8.50)\end{array}$ & - & $\begin{array}{r}-0.7050 \\
(-8.13)\end{array}$ & - & $\begin{array}{r}-0.0239 \\
(-0.43)\end{array}$ & - & $\begin{array}{r}0.7065 \\
(9.05)\end{array}$ & - & $\begin{array}{r}-0.6651 \\
(-9.29)\end{array}$ & - & $\begin{array}{r}-0.0270 \\
(-0.38)\end{array}$ & - & $\begin{array}{r}0.6457 \\
(7.47)\end{array}$ & - & $\begin{array}{r}-0.6850 \\
(-9.12)\end{array}$ \\
\hline$\delta$ & $\begin{array}{r}-0.4758 \\
(-1.94)\end{array}$ & $\begin{array}{r}-1.0101 \\
(-2.99)\end{array}$ & $\begin{array}{r}-0.0826 \\
(-0.56)\end{array}$ & $\begin{array}{r}-0.5962 \\
(-2.26)\end{array}$ & $\begin{array}{r}0.1349 \\
(1.34)\end{array}$ & $\begin{array}{r}0.4670 \\
(2.52)\end{array}$ & $\begin{array}{r}-0.4290 \\
(-1.78)\end{array}$ & $\begin{array}{r}-0.6628 \\
(-3.21)\end{array}$ & $\begin{array}{r}0.1762 \\
(1.01)\end{array}$ & $\begin{array}{r}-0.4581 \\
(-2.68)\end{array}$ & $\begin{array}{r}-0.1593 \\
(-0.92)\end{array}$ & $\begin{array}{r}0.0486 \\
(0.31)\end{array}$ & $\begin{array}{r}-0.2008 \\
(-0.99)\end{array}$ & $\begin{array}{r}-0.6705 \\
(-3.02)\end{array}$ & $\begin{array}{r}0.1279 \\
(0.64)\end{array}$ & $\begin{array}{r}-0.5228 \\
(-2.71)\end{array}$ & $\begin{array}{r}0.1417 \\
(0.75)\end{array}$ & $\begin{array}{r}0.4794 \\
(2.18)\end{array}$ \\
\hline$\omega$ & $\begin{array}{r}0.0002 \\
(2.24)\end{array}$ & $\begin{array}{c}0.0001 \\
(2.47)\end{array}$ & $\begin{array}{c}0.0001 \\
(1.53)\end{array}$ & $\begin{array}{r}0.0000 \\
(1.14)\end{array}$ & $\begin{array}{c}0.0001 \\
(2.32)\end{array}$ & $\begin{array}{r}0.0000 \\
(1.13)\end{array}$ & $\begin{array}{r}0.0003 \\
(1.76)\end{array}$ & $\begin{array}{r}0.0001 \\
(2.54)\end{array}$ & $\begin{array}{c}0.0001 \\
(1.23)\end{array}$ & $\begin{array}{r}0.0000 \\
(0.97)\end{array}$ & $\begin{array}{c}0.0001 \\
(1.75)\end{array}$ & $\begin{array}{c}0.0001 \\
(1.89)\end{array}$ & $\begin{array}{r}0.0001 \\
(1.42)\end{array}$ & $\begin{array}{r}0.0001 \\
(1.97)\end{array}$ & $\begin{array}{r}0.0001 \\
(1.17)\end{array}$ & $\begin{array}{c}0.0001 \\
(2.25)\end{array}$ & $\begin{array}{c}0.0001 \\
(1.58)\end{array}$ & $\begin{array}{r}0.0001 \\
(1.79)\end{array}$ \\
\hline$\gamma$ & $\begin{array}{c}0.2316 \\
(2.66)\end{array}$ & $\begin{array}{r}0.2274 \\
(2.08)\end{array}$ & $\begin{array}{r}0.1965 \\
(2.81)\end{array}$ & $\begin{array}{r}0.1757 \\
(2.76)\end{array}$ & $\begin{array}{r}0.2766 \\
(2.76)\end{array}$ & $\begin{array}{r}0.1391 \\
(2.41)\end{array}$ & $\begin{array}{r}0.2645 \\
(2.43)\end{array}$ & $\begin{array}{c}0.3274 \\
(2.26)\end{array}$ & $\begin{array}{r}0.1758 \\
(2.75)\end{array}$ & $\begin{array}{r}0.1521 \\
(2.89)\end{array}$ & $\begin{array}{r}0.2526 \\
(3.04)\end{array}$ & $\begin{array}{r}0.3033 \\
(4.18)\end{array}$ & $\begin{array}{r}0.1491 \\
(1.90)\end{array}$ & $\begin{array}{r}0.2871 \\
(2.01)\end{array}$ & $\begin{array}{r}0.1411 \\
(3.04)\end{array}$ & $\begin{array}{r}0.2051 \\
(2.81)\end{array}$ & $\begin{array}{r}0.1836 \\
(2.51)\end{array}$ & $\begin{array}{r}0.2010 \\
(2.50)\end{array}$ \\
\hline$\theta$ & $\begin{array}{c}0.5783 \\
(4.34)\end{array}$ & $\begin{array}{c}0.5558 \\
(3.88)\end{array}$ & $\begin{array}{l}0.7871 \\
(11.24)\end{array}$ & $\begin{array}{l}0.8164 \\
(12.78)\end{array}$ & $\begin{array}{l}0.7060 \\
(13.92)\end{array}$ & $\begin{array}{l}0.8581 \\
(14.77)\end{array}$ & $\begin{array}{r}0.4998 \\
(2.52)\end{array}$ & $\begin{array}{r}0.5079 \\
(3.80)\end{array}$ & $\begin{array}{l}0.8034 \\
(10.87)\end{array}$ & $\begin{array}{l}0.8468 \\
(14.69)\end{array}$ & $\begin{array}{c}0.7275 \\
(9.35)\end{array}$ & $\begin{array}{r}0.6882 \\
(9.51)\end{array}$ & $\begin{array}{r}0.7959 \\
(8.00)\end{array}$ & $\begin{array}{r}0.5742 \\
(3.93)\end{array}$ & $\begin{array}{l}0.8280 \\
(11.55)\end{array}$ & $\begin{array}{c}0.7152 \\
(8.64)\end{array}$ & $\begin{array}{r}0.7779 \\
(9.79)\end{array}$ & $\begin{array}{r}0.7192 \\
(7.43)\end{array}$ \\
\hline$\gamma+\theta$ & 0.8099 & 0.7832 & 0.9836 & 0.9921 & 0.9826 & 0.9972 & 0.7643 & 0.8352 & 0.9792 & 0.9989 & 0.9801 & 0.9916 & 0.9450 & 0.8613 & 0.9691 & 0.9203 & 0.9615 & 0.9202 \\
\hline
\end{tabular}




\section{Table 5 - Akaike's information criterion}

The table reports Akaike's information criterion for three specifications of the market model (MM) and the Fama and French model (FFM). These specifications are the static model, the GJR-GARCH(1,1)-M model and the GARCH(1,1)-M model. Winner (Loser) is an equallyweighted non-overlapping portfolio containing the $10 \%$ of stocks that performed the best (worst) over a given ranking period. Momentum is a portfolio that buys the winner portfolio and short sells the loser portfolio. The highlighted entries denote the minimum values for each ranking and holding period.

\begin{tabular}{|c|c|c|c|c|c|c|c|c|c|c|c|c|c|c|c|c|c|c|}
\hline & \multicolumn{6}{|c|}{ Holding period of 3 months } & \multicolumn{6}{|c|}{ Holding period of 6 months } & \multicolumn{6}{|c|}{ Holding period of 12 months } \\
\hline & \multicolumn{2}{|c|}{ Winner } & \multicolumn{2}{|c|}{ Loser } & \multicolumn{2}{|c|}{ Momentum } & \multicolumn{2}{|c|}{ Winner } & \multicolumn{2}{|c|}{ Loser } & \multicolumn{2}{|c|}{ Momentum } & \multicolumn{2}{|c|}{ Winner } & \multicolumn{2}{|c|}{ Loser } & \multicolumn{2}{|c|}{ Momentum } \\
\hline & $\mathrm{MM}$ & FFM & $\mathrm{MM}$ & FFM & $\mathrm{MM}$ & FFM & $\mathrm{MM}$ & FFM & MM & FFM & $\mathrm{MM}$ & FFM & $\mathrm{MM}$ & FFM & $\mathrm{MM}$ & FFM & $\mathrm{MM}$ & $\mathrm{FFM}$ \\
\hline \multicolumn{19}{|c|}{ Panel A: Ranking period of 3 months } \\
\hline Static & -3.5705 & -4.7005 & -3.0319 & -3.6139 & -3.2293 & -3.2527 & -3.4921 & -4.5723 & -3.0299 & -3.6719 & -3.1306 & -3.1827 & -3.3852 & -4.4449 & -3.1774 & -3.9119 & -3.2506 & -3.3900 \\
\hline GJR-GARCH(1,1)-M & -3.8980 & -4.9116 & $\underline{-3.2531}$ & $\underline{-3.9252}$ & $\underline{-3.6228}$ & $\underline{-3.6636}$ & $\underline{-4.0527}$ & -5.0383 & $\underline{-3.3035}$ & -4.1226 & $\underline{-3.5992}$ & $\underline{-3.7186}$ & $\underline{-3.8670}$ & $\underline{-4.8225}$ & $\underline{-3.4542}$ & -4.3080 & $\underline{-3.8732}$ & $\underline{-3.8994}$ \\
\hline GARCH(1,1)-M & $\underline{-3.8930}$ & -4.9180 & -3.2528 & -3.9117 & -3.5990 & -3.6371 & -3.9968 & $\underline{-5.0433}$ & -3.2382 & -4.0912 & -3.5884 & -3.7129 & -3.8314 & -4.8120 & -3.3521 & -4.2663 & -3.8580 & -3.8925 \\
\hline \multicolumn{19}{|c|}{ Panel B: Ranking period of 6 months } \\
\hline Static & -3.5999 & -4.6875 & -2.9686 & -3.5447 & -3.0217 & -3.1060 & -3.5918 & -4.7269 & -3.0307 & -3.6506 & -3.1062 & -3.1966 & -3.5481 & -4.6835 & -3.1310 & -3.7894 & -3.1561 & -3.2989 \\
\hline GJR-GARCH(1,1)-M & -4.0511 & -5.1124 & $\underline{-3.2896}$ & $\underline{-3.9190}$ & -3.3642 & $\underline{-3.6043}$ & $\underline{-4.0917}$ & -5.1440 & $\underline{-3.3278}$ & -4.0353 & $\underline{-3.5974}$ & $\underline{-3.7318}$ & $\underline{-3.9930}$ & $\underline{-5.0968}$ & $\underline{-3.3462}$ & $\underline{-4.0672}$ & $\underline{-3.6856}$ & $\underline{-3.7464}$ \\
\hline GARCH(1,1)-M & $\underline{-4.0545}$ & $\underline{-5.1138}$ & -3.1718 & -3.8702 & $\underline{-3.4429}$ & -3.5613 & -4.0238 & $\underline{-5.1474}$ & -3.2341 & -4.0151 & -3.5494 & -3.6994 & -3.9647 & -5.0967 & -3.2905 & -4.0503 & -3.6769 & -3.7447 \\
\hline \multicolumn{19}{|c|}{ Panel C: Ranking period of 12 months } \\
\hline Static & -3.6854 & -4.7215 & -3.1856 & -3.6968 & -3.1413 & -3.2469 & -3.6710 & -4.7510 & -3.0987 & -3.7613 & -3.1607 & -3.3108 & -3.6950 & -4.8780 & -3.1833 & -3.8806 & -3.3297 & -3.5177 \\
\hline GJR-GARCH(1,1)-M & -4.1297 & -4.9484 & $\underline{-3.4974}$ & -4.0284 & $\underline{-3.5332}$ & $\underline{-3.5948}$ & -3.9877 & $\underline{-5.1261}$ & $\underline{-3.3148}$ & -4.0819 & $\underline{-3.5212}$ & $\underline{-3.6705}$ & -4.0313 & -5.2009 & $\underline{-3.3404}$ & -4.0422 & $\underline{-3.6828}$ & -3.7880 \\
\hline GARCH $(1,1)-M$ & -4.0490 & $\underline{-4.9548}$ & -3.3972 & -3.9636 & -3.4861 & -3.5878 & $\underline{-3.9936}$ & -5.1250 & -3.2375 & -3.9895 & -3.5142 & -3.6411 & -3.9855 & -5.1837 & -3.2587 & -4.0371 & -3.6703 & $\underline{-3.7954}$ \\
\hline
\end{tabular}




\section{Table 6 - Mean return and $p$-values for momentum strategies for various ranking and holding periods for US Data.}

Winner (Loser) is an equally-weighted non-overlapping portfolio containing the $10 \%$ of stocks that performed the best (worst) over a given ranking period. Momentum is a portfolio that buys the winner portfolio and sells the loser portfolio short. Returns are measured as proportions rather than percentages. Reward-to-risk ratio is the ratio of the monthly mean to the monthly standard deviation. The p-values in parentheses are for the significance of the mean. They are based on heteroscedasticity and autocorrelation robust (Newey-West) standard errors.

\begin{tabular}{c} 
Holding period of $\mathbf{3}$ months \\
\cline { 2 - 2 } Winner Loser Momentum
\end{tabular}

\begin{tabular}{cc}
\hline Holding period of 6 months \\
\hline Winner Loser $\quad$ Momentum \\
\hline
\end{tabular}

\begin{tabular}{c}
\hline \multicolumn{3}{l}{ Holding period of $\mathbf{1 2}$ months } \\
\hline Winner Loser $\quad$ Momentum \\
\hline
\end{tabular}

Panel A: Ranking period of 3 months

\begin{tabular}{|c|c|c|c|c|c|c|c|c|c|}
\hline $\begin{array}{l}\text { Mean } \\
p \text {-value }\end{array}$ & $\begin{array}{r}0.0117 \\
(0.00)\end{array}$ & $\begin{array}{r}0.0056 \\
(0.20)\end{array}$ & $\begin{array}{r}0.0061 \\
(0.05)\end{array}$ & $\begin{array}{r}0.0123 \\
(0.00)\end{array}$ & $\begin{array}{r}0.0034 \\
(0.42)\end{array}$ & $\begin{array}{r}0.0089 \\
(0.00)\end{array}$ & $\begin{array}{r}0.0123 \\
(0.00)\end{array}$ & $\begin{array}{r}0.0036 \\
(0.32)\end{array}$ & $\begin{array}{r}0.0087 \\
(0.00)\end{array}$ \\
\hline \multicolumn{10}{|c|}{ Panel B: Ranking period of 6 months } \\
\hline $\begin{array}{l}\text { Mean } \\
p \text {-value }\end{array}$ & $\begin{array}{r}0.0154 \\
(0.00)\end{array}$ & $\begin{array}{r}0.0008 \\
(0.85)\end{array}$ & $\begin{array}{r}0.0147 \\
(0.00)\end{array}$ & $\begin{array}{r}0.0145 \\
(0.00)\end{array}$ & $\begin{array}{r}0.0007 \\
(0.87)\end{array}$ & $\begin{array}{r}0.0139 \\
(0.00)\end{array}$ & $\begin{array}{r}0.0132 \\
(0.00)\end{array}$ & $\begin{array}{r}0.0012 \\
(0.76)\end{array}$ & $\begin{array}{r}0.0120 \\
(0.00)\end{array}$ \\
\hline \multicolumn{10}{|c|}{ Panel C: Ranking period of 12 months } \\
\hline $\begin{array}{l}\text { Mean } \\
p \text {-value }\end{array}$ & $\begin{array}{r}0.0166 \\
(0.00)\end{array}$ & $\begin{array}{c}-0.001 \\
(0.89)\end{array}$ & $\begin{array}{r}0.0171 \\
(0.00)\end{array}$ & $\begin{array}{r}0.0154 \\
(0.00)\end{array}$ & $\begin{array}{r}-0.0010 \\
(0.81)\end{array}$ & $\begin{array}{r}0.0163 \\
(0.00)\end{array}$ & $\begin{array}{r}0.0122 \\
(0.00)\end{array}$ & $\begin{array}{r}0.0010 \\
(0.80)\end{array}$ & $\begin{array}{r}0.0112 \\
(0.00)\end{array}$ \\
\hline
\end{tabular}




\section{Table 7 - Static market and Fama and French models for US Data}

The table reports coefficient estimates for equations (1) and (2) for the winner, loser and momentum portfolios. Winner (Loser) is an equally-weighted non-overlapping portfolio containing the $10 \%$ of stocks that performed the best (worst) over a given ranking period. Momentum is a portfolio that buys the winner portfolio and short sells the loser portfolio. $\alpha$ measures the portfolio abnormal performance, $\beta$ measures the market risk of the portfolio, $s$ and $h$ are the portfolio loadings on the size and book-to-market value factors as measured by Fama and French (1993). MM refers to the market model and FFM refers to the Fama and French model. White's heteroscedasticity robust $t$ statistics are in parentheses.

\begin{tabular}{|c|c|c|c|c|c|c|c|c|c|c|c|c|c|c|c|c|c|c|}
\hline & \multicolumn{6}{|c|}{ Holding period of 3 months } & \multicolumn{6}{|c|}{ Holding period of 6 months } & \multicolumn{6}{|c|}{ Holding period of 12 months } \\
\hline & \multicolumn{2}{|c|}{ Winner } & \multicolumn{2}{|c|}{ Loser } & \multicolumn{2}{|c|}{ Momentum } & \multicolumn{2}{|c|}{ Winner } & \multicolumn{2}{|c|}{ Loser } & \multicolumn{2}{|c|}{ Momentum } & \multicolumn{2}{|c|}{ Winner } & \multicolumn{2}{|c|}{ Loser } & \multicolumn{2}{|c|}{ Momentum } \\
\hline & $\mathrm{MM}$ & FFM & $\mathrm{MM}$ & FFM & $\mathrm{MM}$ & $\mathrm{FFM}$ & $\mathrm{MM}$ & FFM & $\mathrm{MM}$ & FFM & $\mathrm{MM}$ & $\mathrm{FFM}$ & $\mathrm{MM}$ & FFM & $\mathrm{MM}$ & $\mathrm{FFM}$ & $\mathrm{MM}$ & $\mathrm{FFM}$ \\
\hline \multicolumn{19}{|c|}{ Panel A: Ranking period of 3 months } \\
\hline$\alpha$ & $\begin{array}{r}-0.0002 \\
(-0.11)\end{array}$ & $\begin{array}{r}-0.0021 \\
(-1.36)\end{array}$ & $\begin{array}{r}-0.0070 \\
(-2.45)\end{array}$ & $\begin{array}{r}-0.0082 \\
(-3.05)\end{array}$ & $\begin{array}{r}0.0067 \\
(2.21)\end{array}$ & $\begin{array}{r}0.0062 \\
(1.90)\end{array}$ & $\begin{array}{r}0.0003 \\
(0.14)\end{array}$ & $\begin{array}{c}-0.0015 \\
(-1.05)\end{array}$ & $\begin{array}{r}-0.0091 \\
(-3.44)\end{array}$ & $\begin{array}{r}-0.0106 \\
(-4.44)\end{array}$ & $\begin{array}{r}0.0094 \\
(3.81)\end{array}$ & $\begin{array}{c}0.0091 \\
(3.38)\end{array}$ & $\begin{array}{r}0.0000 \\
(0.00)\end{array}$ & $\begin{array}{r}-0.0018 \\
(-1.17)\end{array}$ & $\begin{array}{r}-0.0084 \\
(-3.82)\end{array}$ & $\begin{array}{r}-0.0096 \\
(-4.93)\end{array}$ & $\begin{array}{r}0.0084 \\
(3.83)\end{array}$ & $\begin{array}{r}0.0078 \\
(3.63)\end{array}$ \\
\hline$\beta$ & $\begin{array}{l}1.2058 \\
(20.19)\end{array}$ & $\begin{array}{l}1.1486 \\
(13.57)\end{array}$ & $\begin{array}{l}1.3507 \\
(19.12)\end{array}$ & $\begin{array}{l}1.2593 \\
(16.57)\end{array}$ & $\begin{array}{r}-0.1448 \\
(-1.75)\end{array}$ & $\begin{array}{r}-0.1107 \\
(-1.20)\end{array}$ & $\begin{array}{l}1.2283 \\
(22.22)\end{array}$ & $\begin{array}{l}1.1585 \\
(16.93)\end{array}$ & $\begin{array}{l}1.3129 \\
(20.26)\end{array}$ & $\begin{array}{l}1.2391 \\
(16.34)\end{array}$ & $\begin{array}{r}-0.0846 \\
(-1.22)\end{array}$ & $\begin{array}{r}-0.0806 \\
(-1.19)\end{array}$ & $\begin{array}{l}1.3144 \\
(21.82)\end{array}$ & $\begin{array}{l}1.2370 \\
(15.94)\end{array}$ & $\begin{array}{l}1.1910 \\
(22.33)\end{array}$ & $\begin{array}{l}1.1278 \\
(15.50)\end{array}$ & $\begin{array}{c}0.1234 \\
(1.74)\end{array}$ & $\begin{array}{r}0.1093 \\
(1.42)\end{array}$ \\
\hline$s$ & & $\begin{array}{c}0.8141 \\
(3.80)\end{array}$ & & $\begin{array}{c}0.8650 \\
(5.78)\end{array}$ & & $\begin{array}{r}-0.0508 \\
(-0.30)\end{array}$ & & $\begin{array}{c}0.8710 \\
(5.11)\end{array}$ & & $\begin{array}{c}0.8303 \\
(4.99)\end{array}$ & & $\begin{array}{c}0.0407 \\
(0.38)\end{array}$ & & $\begin{array}{r}0.9282 \\
(4.74)\end{array}$ & & $\begin{array}{c}0.7031 \\
(5.25)\end{array}$ & & $\begin{array}{r}0.2250 \\
(2.02)\end{array}$ \\
\hline$h$ & & $\begin{array}{r}0.2004 \\
(1.63)\end{array}$ & & $\begin{array}{c}0.1207 \\
(0.85)\end{array}$ & & $\begin{array}{r}0.0797 \\
(0.44)\end{array}$ & & $\begin{array}{r}0.1883 \\
(1.94)\end{array}$ & & $\begin{array}{c}0.1577 \\
(1.21)\end{array}$ & & $\begin{array}{c}0.0306 \\
(0.25)\end{array}$ & & $\begin{array}{r}0.1919 \\
(1.57)\end{array}$ & & $\begin{array}{c}0.1314 \\
(1.26)\end{array}$ & & $\begin{array}{r}0.0604 \\
(0.51)\end{array}$ \\
\hline \multicolumn{19}{|c|}{ Panel B: Ranking period of 6 months } \\
\hline$\alpha$ & $\begin{array}{c}0.0031 \\
(1.37)\end{array}$ & $\begin{array}{c}0.0016 \\
(1.11)\end{array}$ & $\begin{array}{r}-0.0115 \\
(-3.99)\end{array}$ & $\begin{array}{r}-0.0127 \\
(-4.54)\end{array}$ & $\begin{array}{r}0.0146 \\
(4.51)\end{array}$ & $\begin{array}{r}0.0143 \\
(4.13)\end{array}$ & $\begin{array}{r}0.0020 \\
(0.93)\end{array}$ & $\begin{array}{r}0.0011 \\
(0.81)\end{array}$ & $\begin{array}{r}-0.0114 \\
(-4.05)\end{array}$ & $\begin{array}{r}-0.0129 \\
(-4.72)\end{array}$ & $\begin{array}{c}0.0134 \\
(4.52)\end{array}$ & $\begin{array}{c}0.0141 \\
(4.29)\end{array}$ & $\begin{array}{r}0.0006 \\
(0.29)\end{array}$ & $\begin{array}{r}-0.0010 \\
(-0.71)\end{array}$ & $\begin{array}{r}-0.0108 \\
(-4.39)\end{array}$ & $\begin{array}{r}-0.0115 \\
(-5.10)\end{array}$ & $\begin{array}{r}0.0115 \\
(4.78)\end{array}$ & $\begin{array}{r}0.0105 \\
(4.16)\end{array}$ \\
\hline$\beta$ & $\begin{array}{l}1.2834 \\
(22.39)\end{array}$ & $\begin{array}{l}1.2107 \\
(14.26)\end{array}$ & $\begin{array}{l}1.3081 \\
(19.05)\end{array}$ & $\begin{array}{c}1.2218 \\
(15.67)\end{array}$ & $\begin{array}{c}-0.0247 \\
(-0.28)\end{array}$ & $\begin{array}{r}-0.0111 \\
(-0.12)\end{array}$ & $\begin{array}{l}1.3048 \\
(22.93)\end{array}$ & $\begin{array}{l}1.2125 \\
(14.33)\end{array}$ & $\begin{array}{l}1.2572 \\
(19.07)\end{array}$ & $\begin{array}{l}1.1855 \\
(14.60)\end{array}$ & $\begin{array}{r}0.0476 \\
(0.58)\end{array}$ & $\begin{array}{c}0.0270 \\
(0.28)\end{array}$ & $\begin{array}{l}1.3586 \\
(24.44)\end{array}$ & $\begin{array}{l}1.2856 \\
(18.08)\end{array}$ & $\begin{array}{l}1.1958 \\
(19.55)\end{array}$ & $\begin{array}{l}1.1020 \\
(13.80)\end{array}$ & $\begin{array}{c}0.1628 \\
(2.26)\end{array}$ & $\begin{array}{r}0.1836 \\
(2.27)\end{array}$ \\
\hline$s$ & & $\begin{array}{r}0.7969 \\
(3.72)\end{array}$ & & $\begin{array}{c}0.8084 \\
(4.99)\end{array}$ & & $\begin{array}{r}-0.0115 \\
(-0.07)\end{array}$ & & $\begin{array}{c}0.7656 \\
(3.56)\end{array}$ & & $\begin{array}{c}0.8314 \\
(5.25)\end{array}$ & & $\begin{array}{r}-0.0659 \\
(-0.40)\end{array}$ & & $\begin{array}{c}0.8587 \\
(4.96)\end{array}$ & & $\begin{array}{c}0.7298 \\
(4.69)\end{array}$ & & $\begin{array}{r}0.1289 \\
(1.31)\end{array}$ \\
\hline$h$ & & $\begin{array}{r}0.1457 \\
(1.19)\end{array}$ & & $\begin{array}{r}0.1102 \\
(0.72)\end{array}$ & & $\begin{array}{r}0.0355 \\
(0.18)\end{array}$ & & $\begin{array}{c}0.0723 \\
(0.58)\end{array}$ & & $\begin{array}{r}0.1648 \\
(1.16)\end{array}$ & & $\begin{array}{r}-0.0925 \\
(-0.54)\end{array}$ & & $\begin{array}{c}0.1732 \\
(1.67)\end{array}$ & & $\begin{array}{r}0.0515 \\
(0.43)\end{array}$ & & $\begin{array}{r}0.1217 \\
(1.05)\end{array}$ \\
\hline \multicolumn{19}{|c|}{ Panel C: Ranking period of 12 months } \\
\hline$\alpha$ & $\begin{array}{r}0.0038 \\
(1.73)\end{array}$ & $\begin{array}{c}0.0036 \\
(2.38)\end{array}$ & $\begin{array}{r}-0.0125 \\
(-4.62)\end{array}$ & $\begin{array}{c}-0.0138 \\
(-4.94)\end{array}$ & $\begin{array}{c}0.0163 \\
(5.15)\end{array}$ & $\begin{array}{r}0.0174 \\
(4.89)\end{array}$ & $\begin{array}{r}0.0027 \\
(1.24)\end{array}$ & $\begin{array}{r}0.0026 \\
(1.78)\end{array}$ & $\begin{array}{r}-0.0131 \\
(-4.94)\end{array}$ & $\begin{array}{r}-0.0147 \\
(-5.63)\end{array}$ & $\begin{array}{r}0.0157 \\
(5.27)\end{array}$ & $\begin{array}{r}0.0172 \\
(5.29)\end{array}$ & $\begin{array}{r}-0.0006 \\
(-0.31)\end{array}$ & $\begin{array}{r}-0.0011 \\
(-0.87)\end{array}$ & $\begin{array}{r}-0.0108 \\
(-4.25)\end{array}$ & $\begin{array}{r}-0.0127 \\
(-5.23)\end{array}$ & $\begin{array}{r}0.0102 \\
(3.71)\end{array}$ & $\begin{array}{r}0.0116 \\
(4.00)\end{array}$ \\
\hline$\beta$ & $\begin{array}{l}1.3729 \\
(24.99)\end{array}$ & $\begin{array}{l}1.2558 \\
(15.65)\end{array}$ & $\begin{array}{l}1.2014 \\
(17.33)\end{array}$ & $\begin{array}{l}1.1341 \\
(13.70)\end{array}$ & $\begin{array}{r}0.1716 \\
(1.85)\end{array}$ & $\begin{array}{r}0.1217 \\
(1.15)\end{array}$ & $\begin{array}{l}1.3604 \\
(25.64)\end{array}$ & $\begin{array}{l}1.2400 \\
(15.53)\end{array}$ & $\begin{array}{l}1.2268 \\
(19.03)\end{array}$ & $\begin{array}{l}1.1632 \\
(15.31)\end{array}$ & $\begin{array}{r}0.1336 \\
(1.64)\end{array}$ & $\begin{array}{r}0.0768 \\
(0.80)\end{array}$ & $\begin{array}{l}1.3866 \\
(28.86)\end{array}$ & $\begin{array}{l}1.2821 \\
(16.65)\end{array}$ & $\begin{array}{l}1.1740 \\
(18.45)\end{array}$ & $\begin{array}{l}1.1245 \\
(16.36)\end{array}$ & $\begin{array}{r}0.2126 \\
(2.92)\end{array}$ & $\begin{array}{r}0.1575 \\
(1.87)\end{array}$ \\
\hline$s$ & & $\begin{array}{c}0.7214 \\
(3.65)\end{array}$ & & $\begin{array}{c}0.7224 \\
(5.07)\end{array}$ & & $\begin{array}{r}-0.0010 \\
(-0.01)\end{array}$ & & $\begin{array}{r}0.7102 \\
(3.60)\end{array}$ & & $\begin{array}{r}0.7870 \\
(5.63)\end{array}$ & & $\begin{array}{r}-0.0768 \\
(-0.49)\end{array}$ & & $\begin{array}{r}0.7276 \\
(3.71)\end{array}$ & & $\begin{array}{r}0.7879 \\
(5.94)\end{array}$ & & $\begin{array}{r}-0.0603 \\
(-0.40)\end{array}$ \\
\hline$h$ & & $\begin{array}{r}-0.0229 \\
(-0.20) \\
\end{array}$ & & $\begin{array}{r}0.1280 \\
(0.94) \\
\end{array}$ & & $\begin{array}{r}-0.1509 \\
(-0.85) \\
\end{array}$ & & $\begin{array}{r}-0.0377 \\
(-0.32) \\
\end{array}$ & & $\begin{array}{r}0.1689 \\
(1.31)\end{array}$ & & $\begin{array}{r}-0.2066 \\
(-1.23) \\
\end{array}$ & & $\begin{array}{r}0.0179 \\
(0.16) \\
\end{array}$ & & $\begin{array}{c}0.2117 \\
(1.68)\end{array}$ & & $\begin{array}{r}-0.1938 \\
(-1.18)\end{array}$ \\
\hline
\end{tabular}


Table 8 - Conditional market and Fama and French models with a GJR-GARCH (1, 1)-M term for US Data

The table reports coefficient estimates for systems (3) and (4) for the winner, loser and momentum portfolios. Winner (Loser) is an equallyweighted non-overlapping portfolio containing the $10 \%$ of stocks that performed the best (worst) over a given ranking period. Momentum is a portfolio that buys the winner portfolio and short sells the loser portfolio. $\alpha$ measures the portfolio abnormal performance, $\beta$ measures the market risk of the portfolio, $s$ and $h$ are the portfolio loadings on the size and book-to-market value factors as measured by Fama and French (1993), $\delta \sigma_{t}$ is the time-varying risk exposure. The conditional variance of the portfolio returns follows a GJR-GARCH(1,1) structure as $\sigma_{t}^{2}=\omega+\gamma \varepsilon_{t-1}^{2}+\eta I_{t-1} \varepsilon_{t-1}^{2}+\theta \sigma_{t-1}^{2}$, where $\omega, \gamma, \eta$ and $\theta$ are estimated parameters and $I_{t-1}$ takes a value of 1 , when $\varepsilon_{t-1}$ is negative and a value of 0 , otherwise. MM refers to the market model and FFM refers to the Fama and French model. Bollerslev-Wooldridge robust $t$-statistics are in parentheses.

\begin{tabular}{|c|c|c|c|c|c|c|c|c|c|c|c|c|c|c|c|c|c|c|}
\hline & \multicolumn{6}{|c|}{ Holding period of 3 months } & \multicolumn{6}{|c|}{ Holding period of 6 months } & \multicolumn{6}{|c|}{ Holding period of 12 months } \\
\hline & \multicolumn{2}{|c|}{ Winner } & \multicolumn{2}{|c|}{ Loser } & \multicolumn{2}{|c|}{ Momentum } & \multicolumn{2}{|c|}{ Winner } & \multicolumn{2}{|c|}{ Loser } & \multicolumn{2}{|c|}{ Momentum } & \multicolumn{2}{|c|}{ Winner } & \multicolumn{2}{|c|}{ Loser } & \multicolumn{2}{|c|}{ Momentum } \\
\hline & $\mathrm{MM}$ & FFM & $\mathrm{MM}$ & FFM & $\mathrm{MM}$ & FFM & $\mathrm{MM}$ & FFM & $\mathrm{MM}$ & FFM & $\mathrm{MM}$ & FFM & $\mathrm{MM}$ & FFM & $\mathrm{MM}$ & FFM & $\mathrm{MM}$ & FFM \\
\hline \multicolumn{19}{|c|}{ Panel A: Ranking period of 3 months } \\
\hline$\alpha$ & $\begin{array}{r}-0.0248 \\
(-2.51)\end{array}$ & $\begin{array}{r}-0.0087 \\
(-1.74)\end{array}$ & $\begin{array}{r}-0.0115 \\
(-1.09)\end{array}$ & $\begin{array}{r}-0.0133 \\
(-2.97)\end{array}$ & $\begin{array}{r}0.0245 \\
(3.40)\end{array}$ & $\begin{array}{r}0.0253 \\
(3.42)\end{array}$ & $\begin{array}{r}-0.0391 \\
(-2.67)\end{array}$ & $\begin{array}{r}0.0171 \\
(1.46)\end{array}$ & $\begin{array}{r}-0.0207 \\
(-2.72)\end{array}$ & $\begin{array}{r}-0.0133 \\
(-3.62)\end{array}$ & $\begin{array}{c}0.0143 \\
(2.84)\end{array}$ & $\begin{array}{c}0.0159 \\
(3.08)\end{array}$ & $\begin{array}{r}0.0005 \\
(0.04)\end{array}$ & $\begin{array}{c}-0.0073 \\
(-1.05)\end{array}$ & $\begin{array}{r}-0.0064 \\
(-0.91)\end{array}$ & $\begin{array}{r}-0.0189 \\
(-4.94)\end{array}$ & $\begin{array}{c}0.0093 \\
(1.51)\end{array}$ & $\begin{array}{c}0.0124 \\
(1.95)\end{array}$ \\
\hline$\beta$ & $\begin{array}{l}1.1271 \\
(32.96)\end{array}$ & $\begin{array}{l}1.0513 \\
(42.37)\end{array}$ & $\begin{array}{l}1.1243 \\
(13.79)\end{array}$ & $\begin{array}{c}1.0959 \\
(21.68)\end{array}$ & $\begin{array}{c}0.0346 \\
(0.75)\end{array}$ & $\begin{array}{c}0.0095 \\
(0.18)\end{array}$ & $\begin{array}{l}1.1675 \\
(31.72)\end{array}$ & $\begin{array}{l}1.0877 \\
(37.89)\end{array}$ & $\begin{array}{l}1.1518 \\
(29.14)\end{array}$ & $\begin{array}{l}1.0468 \\
(31.71)\end{array}$ & $\begin{array}{r}0.0559 \\
(1.45)\end{array}$ & $\begin{array}{c}0.0261 \\
(0.60)\end{array}$ & $\begin{array}{c}1.2776 \\
(31.22)\end{array}$ & $\begin{array}{l}1.1693 \\
(34.54)\end{array}$ & $\begin{array}{l}1.1252 \\
(28.55)\end{array}$ & $\begin{array}{l}1.0158 \\
(31.95)\end{array}$ & $\begin{array}{c}0.1040 \\
(3.20)\end{array}$ & $\begin{array}{r}0.0934 \\
(2.55)\end{array}$ \\
\hline$s$ & & $\begin{array}{l}1.0197 \\
(28.28)\end{array}$ & & $\begin{array}{c}1.0474 \\
(12.06)\end{array}$ & & $\begin{array}{r}0.0156 \\
(0.22)\end{array}$ & & $\begin{array}{l}1.0988 \\
(29.23)\end{array}$ & & $\begin{array}{c}1.0313 \\
(20.20)\end{array}$ & & $\begin{array}{r}0.0837 \\
(1.43)\end{array}$ & & $\begin{array}{c}1.0943 \\
(24.68)\end{array}$ & & $\begin{array}{l}0.9380 \\
(19.43)\end{array}$ & & $\begin{array}{r}0.1798 \\
(3.44)\end{array}$ \\
\hline$h$ & & $\begin{array}{r}-0.0209 \\
(-0.52)\end{array}$ & & $\begin{array}{r}0.0848 \\
(1.32)\end{array}$ & & $\begin{array}{r}-0.1052 \\
(-1.21)\end{array}$ & & $\begin{array}{r}0.0614 \\
(1.47)\end{array}$ & & $\begin{array}{r}0.0831 \\
(1.41)\end{array}$ & & $\begin{array}{r}-0.1046 \\
(-1.47)\end{array}$ & & $\begin{array}{r}0.1646 \\
(3.53)\end{array}$ & & $\begin{array}{c}0.0095 \\
(0.18)\end{array}$ & & $\begin{array}{r}-0.0267 \\
(-0.41)\end{array}$ \\
\hline$\delta$ & $\begin{array}{r}0.6379 \\
(2.32)\end{array}$ & $\begin{array}{r}0.2654 \\
(1.30)\end{array}$ & $\begin{array}{r}0.1217 \\
(0.52)\end{array}$ & $\begin{array}{r}0.1003 \\
(0.72)\end{array}$ & $\begin{array}{r}-0.3409 \\
(-1.96)\end{array}$ & $\begin{array}{r}-0.3463 \\
(-1.93)\end{array}$ & $\begin{array}{c}1.0231 \\
(2.63)\end{array}$ & $\begin{array}{r}-0.7667 \\
(-1.58)\end{array}$ & $\begin{array}{r}0.2944 \\
(1.60)\end{array}$ & $\begin{array}{r}0.0880 \\
(0.70)\end{array}$ & $\begin{array}{c}-0.1184 \\
(-0.82)\end{array}$ & $\begin{array}{c}-0.1404 \\
(-0.95)\end{array}$ & $\begin{array}{r}-0.0399 \\
(-0.12)\end{array}$ & $\begin{array}{r}0.2105 \\
(0.72)\end{array}$ & $\begin{array}{r}-0.0440 \\
(-0.22)\end{array}$ & $\begin{array}{r}0.3082 \\
(2.14)\end{array}$ & $\begin{array}{r}-0.0319 \\
(-0.17)\end{array}$ & $\begin{array}{r}-0.1223 \\
(-0.64)\end{array}$ \\
\hline$\omega$ & $\begin{array}{c}0.0004 \\
(2.43)\end{array}$ & $\begin{array}{r}0.0002 \\
(2.87)\end{array}$ & $\begin{array}{r}0.0003 \\
(2.07)\end{array}$ & $\begin{array}{c}0.0001 \\
(1.90)\end{array}$ & $\begin{array}{r}0.0003 \\
(2.72)\end{array}$ & $\begin{array}{c}0.0003 \\
(2.71)\end{array}$ & $\begin{array}{c}0.0004 \\
(2.24)\end{array}$ & $\begin{array}{r}0.0003 \\
(1.80)\end{array}$ & $\begin{array}{c}0.0001 \\
(3.21)\end{array}$ & $\begin{array}{r}0.0001 \\
(2.30)\end{array}$ & $\begin{array}{r}0.0002 \\
(2.01)\end{array}$ & $\begin{array}{r}0.0002 \\
(2.04)\end{array}$ & $\begin{array}{c}0.0003 \\
(1.78)\end{array}$ & $\begin{array}{c}0.0004 \\
(7.15)\end{array}$ & $\begin{array}{r}0.0000 \\
(1.60)\end{array}$ & $\begin{array}{r}0.0001 \\
(2.37)\end{array}$ & $\begin{array}{c}0.0001 \\
(1.73)\end{array}$ & $\begin{array}{r}0.0001 \\
(1.70)\end{array}$ \\
\hline$\gamma$ & $\begin{array}{r}0.4716 \\
(2.65)\end{array}$ & $\begin{array}{r}0.4717 \\
(3.43)\end{array}$ & $\begin{array}{r}-0.0057 \\
(-0.19)\end{array}$ & $\begin{array}{r}-0.0157 \\
(-0.39)\end{array}$ & $\begin{array}{c}0.4838 \\
(3.37)\end{array}$ & $\begin{array}{r}0.4857 \\
(3.27)\end{array}$ & $\begin{array}{r}0.2845 \\
(2.06)\end{array}$ & $\begin{array}{r}0.0550 \\
(0.69)\end{array}$ & $\begin{array}{r}-0.0036 \\
(-0.18)\end{array}$ & $\begin{array}{r}0.0442 \\
(0.91)\end{array}$ & $\begin{array}{r}0.5406 \\
(3.03)\end{array}$ & $\begin{array}{r}0.5203 \\
(2.92)\end{array}$ & $\begin{array}{r}0.1017 \\
(1.69)\end{array}$ & $\begin{array}{r}0.0295 \\
(0.37)\end{array}$ & $\begin{array}{c}0.0250 \\
(0.85)\end{array}$ & $\begin{array}{r}0.0606 \\
(1.23)\end{array}$ & $\begin{array}{c}0.2762 \\
(2.05)\end{array}$ & $\begin{array}{r}0.2412 \\
(2.02)\end{array}$ \\
\hline$\eta$ & $\begin{array}{r}-0.3916 \\
(-2.31)\end{array}$ & $\begin{array}{r}-0.3296 \\
(-2.07)\end{array}$ & $\begin{array}{r}0.4769 \\
(3.04)\end{array}$ & $\begin{array}{c}0.6649 \\
(3.68)\end{array}$ & $\begin{array}{r}-0.5105 \\
(-3.46)\end{array}$ & $\begin{array}{r}-0.5105 \\
(-3.37)\end{array}$ & $\begin{array}{r}-0.2585 \\
(-1.94)\end{array}$ & $\begin{array}{r}0.1486 \\
(0.97)\end{array}$ & $\begin{array}{c}0.2371 \\
(4.19)\end{array}$ & $\begin{array}{c}0.5284 \\
(3.19)\end{array}$ & $\begin{array}{r}-0.4020 \\
(-2.33)\end{array}$ & $\begin{array}{r}-0.3968 \\
(-2.33)\end{array}$ & $\begin{array}{c}0.0472 \\
(0.58)\end{array}$ & $\begin{array}{r}-0.0419 \\
(-0.29)\end{array}$ & $\begin{array}{r}0.1188 \\
(2.15)\end{array}$ & $\begin{array}{c}0.3862 \\
(2.70)\end{array}$ & $\begin{array}{r}-0.1068 \\
(-0.85)\end{array}$ & $\begin{array}{c}-0.1011 \\
(-0.90)\end{array}$ \\
\hline$\theta$ & $\begin{array}{r}0.4973 \\
(3.67)\end{array}$ & $\begin{array}{r}0.4913 \\
(5.57)\end{array}$ & $\begin{array}{r}0.6899 \\
(6.36)\end{array}$ & $\begin{array}{c}0.6744 \\
(12.44)\end{array}$ & $\begin{array}{l}0.7281 \\
(11.61)\end{array}$ & $\begin{array}{c}0.7202 \\
(10.98)\end{array}$ & $\begin{array}{r}0.5557 \\
(3.69)\end{array}$ & $\begin{array}{r}0.4380 \\
(1.52)\end{array}$ & $\begin{array}{l}0.8421 \\
(30.39)\end{array}$ & $\begin{array}{r}0.6822 \\
(9.28)\end{array}$ & $\begin{array}{r}0.6211 \\
(6.08)\end{array}$ & $\begin{array}{r}0.6320 \\
(6.20)\end{array}$ & $\begin{array}{r}0.6957 \\
(5.38)\end{array}$ & $\begin{array}{r}0.4779 \\
(6.74)\end{array}$ & $\begin{array}{l}0.9009 \\
(23.87)\end{array}$ & $\begin{array}{c}0.7274 \\
(11.57)\end{array}$ & $\begin{array}{r}0.6944 \\
(6.25)\end{array}$ & $\begin{array}{r}0.7330 \\
(7.31)\end{array}$ \\
\hline$\gamma+\eta / 2+\theta$ & 0.7731 & 0.7982 & 0.9226 & 0.9911 & 0.9566 & 0.9506 & 0.7109 & 0.5674 & 0.9570 & 0.9905 & 0.9607 & 0.9540 & 0.8210 & 0.4864 & 0.9853 & 0.9811 & 0.9172 & 0.9236 \\
\hline
\end{tabular}


Table 8 - Continued

\begin{tabular}{|c|c|c|c|c|c|c|c|c|c|c|c|c|c|c|c|c|c|c|}
\hline & \multicolumn{6}{|c|}{ Holding period of 3 months } & \multicolumn{6}{|c|}{ Holding period of 6 months } & \multicolumn{6}{|c|}{ Holding period of 12 months } \\
\hline & \multicolumn{2}{|c|}{ Winner } & \multicolumn{2}{|c|}{ Loser } & \multicolumn{2}{|c|}{ Momentum } & \multicolumn{2}{|c|}{ Winner } & \multicolumn{2}{|c|}{ Loser } & \multicolumn{2}{|c|}{ Momentum } & \multicolumn{2}{|c|}{ Winner } & \multicolumn{2}{|c|}{ Loser } & \multicolumn{2}{|c|}{ Momentum } \\
\hline & $\mathrm{MM}$ & FFM & $\mathrm{MM}$ & FFM & $\mathrm{MM}$ & FFM & $\mathrm{MM}$ & $\mathrm{FFM}$ & $\mathrm{MM}$ & FFM & $\mathrm{MM}$ & FFM & $\mathrm{MM}$ & FFM & $\mathrm{MM}$ & $\mathrm{FFM}$ & $\mathrm{MM}$ & $\mathrm{FFM}$ \\
\hline \multicolumn{19}{|c|}{ Panel B: Ranking period of 6 months } \\
\hline$\alpha$ & $\begin{array}{r}-0.0174 \\
(-1.91)\end{array}$ & $\begin{array}{r}-0.0028 \\
(-0.51)\end{array}$ & $\begin{array}{r}-0.0039 \\
(-0.52)\end{array}$ & $\begin{array}{r}-0.0197 \\
(-3.18)\end{array}$ & $\begin{array}{r}0.0192 \\
(2.82)\end{array}$ & $\begin{array}{r}0.0203 \\
(2.89)\end{array}$ & $\begin{array}{r}-0.0117 \\
(-1.22)\end{array}$ & $\begin{array}{c}0.0014 \\
(0.17)\end{array}$ & $\begin{array}{c}0.0014 \\
(0.17)\end{array}$ & $\begin{array}{r}-0.0142 \\
(-3.11)\end{array}$ & $\begin{array}{r}0.0085 \\
(0.89)\end{array}$ & $\begin{array}{r}0.0112 \\
(1.11)\end{array}$ & $\begin{array}{c}-0.2392 \\
(-1.45)\end{array}$ & $\begin{array}{c}-0.0160 \\
(-1.91)\end{array}$ & $\begin{array}{r}0.0015 \\
(0.25)\end{array}$ & $\begin{array}{r}-0.0174 \\
(-3.23)\end{array}$ & $\begin{array}{r}0.0008 \\
(0.08)\end{array}$ & $\begin{array}{r}0.0032 \\
(0.30)\end{array}$ \\
\hline$\beta$ & $\begin{array}{l}1.2400 \\
(34.06)\end{array}$ & $\begin{array}{l}1.1250 \\
(40.46)\end{array}$ & $\begin{array}{l}1.1771 \\
(26.58)\end{array}$ & $\begin{array}{l}1.0552 \\
(15.66)\end{array}$ & $\begin{array}{r}0.1688 \\
(3.92)\end{array}$ & $\begin{array}{r}0.1453 \\
(2.80)\end{array}$ & $\begin{array}{l}1.2786 \\
(36.76)\end{array}$ & $\begin{array}{l}1.1372 \\
(42.06)\end{array}$ & $\begin{array}{l}1.0883 \\
(21.92)\end{array}$ & $\begin{array}{l}1.0537 \\
(29.77)\end{array}$ & $\begin{array}{r}0.1658 \\
(3.73)\end{array}$ & $\begin{array}{r}0.0677 \\
(1.43)\end{array}$ & $\begin{array}{l}1.3557 \\
(33.14)\end{array}$ & $\begin{array}{l}1.1951 \\
(38.90)\end{array}$ & $\begin{array}{l}1.0790 \\
(24.69)\end{array}$ & $\begin{array}{l}0.9493 \\
(28.10)\end{array}$ & $\begin{array}{r}0.2068 \\
(4.95)\end{array}$ & $\begin{array}{r}0.2343 \\
(4.73)\end{array}$ \\
\hline$s$ & & $\begin{array}{l}1.0736 \\
(29.40)\end{array}$ & & $\begin{array}{l}0.9813 \\
(11.67)\end{array}$ & & $\begin{array}{r}0.0004 \\
(0.01)\end{array}$ & & $\begin{array}{l}1.0342 \\
(28.03)\end{array}$ & & $\begin{array}{l}0.9924 \\
(17.17)\end{array}$ & & $\begin{array}{r}-0.0038 \\
(-0.05)\end{array}$ & & $\begin{array}{l}1.0232 \\
(25.07)\end{array}$ & & $\begin{array}{l}0.8273 \\
(15.63)\end{array}$ & & $\begin{array}{r}0.1708 \\
(2.44)\end{array}$ \\
\hline$h$ & & $\begin{array}{c}-0.0697 \\
(-1.50)\end{array}$ & & $\begin{array}{r}0.2133 \\
(2.55)\end{array}$ & & $\begin{array}{r}-0.0866 \\
(-0.99)\end{array}$ & & $\begin{array}{r}-0.1439 \\
(-3.60)\end{array}$ & & $\begin{array}{r}0.2158 \\
(3.36)\end{array}$ & & $\begin{array}{r}-0.3584 \\
(-4.68)\end{array}$ & & $\begin{array}{c}-0.0299 \\
(-0.60)\end{array}$ & & $\begin{array}{r}-0.1060 \\
(-1.81)\end{array}$ & & $\begin{array}{r}0.1019 \\
(1.22)\end{array}$ \\
\hline$\delta$ & $\begin{array}{r}0.5419 \\
(2.09)\end{array}$ & $\begin{array}{r}0.1743 \\
(0.65)\end{array}$ & $\begin{array}{r}-0.1789 \\
(-1.00)\end{array}$ & $\begin{array}{c}0.1440 \\
(0.79)\end{array}$ & $\begin{array}{r}-0.0802 \\
(-0.49)\end{array}$ & $\begin{array}{r}-0.0923 \\
(-0.55)\end{array}$ & $\begin{array}{r}0.3632 \\
(1.32)\end{array}$ & $\begin{array}{r}-0.0308 \\
(-0.08)\end{array}$ & $\begin{array}{r}-0.2375 \\
(-1.19)\end{array}$ & $\begin{array}{r}-0.0126 \\
(-0.08)\end{array}$ & $\begin{array}{r}0.1617 \\
(0.72)\end{array}$ & $\begin{array}{r}0.1438 \\
(0.61)\end{array}$ & $\begin{array}{r}6.0567 \\
(1.44)\end{array}$ & $\begin{array}{r}0.5939 \\
(1.62)\end{array}$ & $\begin{array}{r}-0.2955 \\
(-1.90)\end{array}$ & $\begin{array}{r}0.1752 \\
(1.02)\end{array}$ & $\begin{array}{r}0.2716 \\
(0.96)\end{array}$ & $\begin{array}{r}0.1911 \\
(0.70)\end{array}$ \\
\hline$\omega$ & $\begin{array}{c}0.0003 \\
(2.35)\end{array}$ & $\begin{array}{c}0.0001 \\
(2.60)\end{array}$ & $\begin{array}{r}0.0002 \\
(2.03)\end{array}$ & $\begin{array}{r}0.0004 \\
(3.47)\end{array}$ & $\begin{array}{r}0.0006 \\
(3.89)\end{array}$ & $\begin{array}{r}0.0006 \\
(3.67)\end{array}$ & $\begin{array}{r}0.0002 \\
(2.16)\end{array}$ & $\begin{array}{c}0.0003 \\
(1.59)\end{array}$ & $\begin{array}{c}0.0001 \\
(1.81)\end{array}$ & $\begin{array}{r}0.0001 \\
(2.59)\end{array}$ & $\begin{array}{r}0.0005 \\
(2.09)\end{array}$ & $\begin{array}{r}0.0005 \\
(1.97)\end{array}$ & $\begin{array}{r}0.0009 \\
(2.37)\end{array}$ & $\begin{array}{c}0.0003 \\
(4.22)\end{array}$ & $\begin{array}{r}0.0000 \\
(1.20)\end{array}$ & $\begin{array}{c}0.0001 \\
(2.36)\end{array}$ & $\begin{array}{r}0.0003 \\
(1.94)\end{array}$ & $\begin{array}{r}0.0002 \\
(1.83)\end{array}$ \\
\hline$\gamma$ & $\begin{array}{c}0.3611 \\
(2.85)\end{array}$ & $\begin{array}{r}0.1885 \\
(3.40)\end{array}$ & $\begin{array}{c}-0.0043 \\
(-0.26)\end{array}$ & $\begin{array}{r}0.1285 \\
(1.55)\end{array}$ & $\begin{array}{r}0.8697 \\
(3.65)\end{array}$ & $\begin{array}{r}0.8612 \\
(3.46)\end{array}$ & $\begin{array}{r}0.2314 \\
(2.78)\end{array}$ & $\begin{array}{r}0.0120 \\
(0.34)\end{array}$ & $\begin{array}{r}-0.0230 \\
(-0.91)\end{array}$ & $\begin{array}{r}0.0266 \\
(0.92)\end{array}$ & $\begin{array}{c}0.5761 \\
(2.44)\end{array}$ & $\begin{array}{r}0.5012 \\
(2.31)\end{array}$ & $\begin{array}{r}0.0159 \\
(1.23)\end{array}$ & $\begin{array}{r}0.3516 \\
(5.39)\end{array}$ & $\begin{array}{r}-0.0119 \\
(-0.84)\end{array}$ & $\begin{array}{c}0.0261 \\
(0.68)\end{array}$ & $\begin{array}{r}0.3063 \\
(2.55)\end{array}$ & $\begin{array}{r}0.2866 \\
(2.57)\end{array}$ \\
\hline$\eta$ & $\begin{array}{r}-0.3564 \\
(-2.76)\end{array}$ & $\begin{array}{r}-0.1121 \\
(-1.65)\end{array}$ & $\begin{array}{c}0.4418 \\
(2.93)\end{array}$ & $\begin{array}{c}0.6588 \\
(3.26)\end{array}$ & $\begin{array}{c}-0.7945 \\
(-3.26)\end{array}$ & $\begin{array}{r}-0.7886 \\
(-3.08)\end{array}$ & $\begin{array}{c}-0.2195 \\
(-2.65)\end{array}$ & $\begin{array}{c}0.2999 \\
(1.88)\end{array}$ & $\begin{array}{c}0.4435 \\
(3.63)\end{array}$ & $\begin{array}{c}0.7130 \\
(3.79)\end{array}$ & $\begin{array}{r}-0.5347 \\
(-2.21)\end{array}$ & $\begin{array}{r}-0.4499 \\
(-2.00)\end{array}$ & $\begin{array}{r}-0.0236 \\
(-1.17)\end{array}$ & $\begin{array}{r}-0.0613 \\
(-0.44)\end{array}$ & $\begin{array}{c}0.2101 \\
(2.93)\end{array}$ & $\begin{array}{c}0.4028 \\
(3.02)\end{array}$ & $\begin{array}{r}-0.2895 \\
(-2.29)\end{array}$ & $\begin{array}{r}-0.2736 \\
(-2.36)\end{array}$ \\
\hline$\theta$ & $\begin{array}{r}0.6556 \\
(6.24)\end{array}$ & $\begin{array}{l}0.7499 \\
(13.14)\end{array}$ & $\begin{array}{l}0.7618 \\
(11.89)\end{array}$ & $\begin{array}{r}0.4320 \\
(5.77)\end{array}$ & $\begin{array}{r}0.4141 \\
(4.16)\end{array}$ & $\begin{array}{r}0.4164 \\
(4.05)\end{array}$ & $\begin{array}{r}0.7684 \\
(9.68)\end{array}$ & $\begin{array}{r}0.3713 \\
(1.13)\end{array}$ & $\begin{array}{l}0.7966 \\
(11.77)\end{array}$ & $\begin{array}{r}0.6056 \\
(7.27)\end{array}$ & $\begin{array}{r}0.5783 \\
(4.07)\end{array}$ & $\begin{array}{r}0.5684 \\
(3.52)\end{array}$ & $\begin{array}{r}0.3807 \\
(1.55)\end{array}$ & $\begin{array}{r}0.2814 \\
(2.80)\end{array}$ & $\begin{array}{c}0.8716 \\
(22.67)\end{array}$ & $\begin{array}{l}0.7358 \\
(10.24)\end{array}$ & $\begin{array}{r}0.7149 \\
(6.95)\end{array}$ & $\begin{array}{r}0.7590 \\
(8.23)\end{array}$ \\
\hline$\gamma+\eta / 2+\theta$ & 0.8385 & 0.8823 & 0.9784 & 0.8899 & 0.8865 & 0.8832 & 0.8901 & 0.5333 & 0.9954 & 0.9887 & 0.8871 & 0.8447 & 0.3847 & 0.6024 & 0.9648 & 0.9633 & 0.8765 & 0.9087 \\
\hline \multicolumn{19}{|c|}{ Panel C: Ranking period of 12 months } \\
\hline$\alpha$ & $\begin{array}{r}0.0030 \\
(0.29)\end{array}$ & $\begin{array}{r}0.0026 \\
(0.81)\end{array}$ & $\begin{array}{r}-0.0067 \\
(-1.21)\end{array}$ & $\begin{array}{r}-0.0215 \\
(-4.72)\end{array}$ & $\begin{array}{r}0.0258 \\
(2.79)\end{array}$ & $\begin{array}{r}0.0286 \\
(3.16)\end{array}$ & $\begin{array}{r}0.0032 \\
(0.29)\end{array}$ & $\begin{array}{c}0.0021 \\
(0.43)\end{array}$ & $\begin{array}{r}-0.0033 \\
(-0.55)\end{array}$ & $\begin{array}{r}-0.0165 \\
(-3.55)\end{array}$ & $\begin{array}{r}0.0179 \\
(2.08)\end{array}$ & $\begin{array}{r}0.0204 \\
(2.25)\end{array}$ & $\begin{array}{r}0.0040 \\
(0.31)\end{array}$ & $\begin{array}{r}-0.0011 \\
(-0.29)\end{array}$ & $\begin{array}{r}-0.0018 \\
(-0.27)\end{array}$ & $\begin{array}{r}-0.0134 \\
(-3.09)\end{array}$ & $\begin{array}{r}0.0081 \\
(0.83)\end{array}$ & $\begin{array}{r}0.0073 \\
(0.75)\end{array}$ \\
\hline$\beta$ & $\begin{array}{l}1.3219 \\
(34.24)\end{array}$ & $\begin{array}{l}1.2280 \\
(36.83)\end{array}$ & $\begin{array}{l}1.0630 \\
(23.09)\end{array}$ & $\begin{array}{c}0.8895 \\
(16.85)\end{array}$ & $\begin{array}{r}0.3319 \\
(6.35)\end{array}$ & $\begin{array}{r}0.2280 \\
(3.98)\end{array}$ & $\begin{array}{l}1.3202 \\
(33.08)\end{array}$ & $\begin{array}{l}1.1897 \\
(40.93)\end{array}$ & $\begin{array}{l}1.1213 \\
(28.55)\end{array}$ & $\begin{array}{l}0.9930 \\
(25.29)\end{array}$ & $\begin{array}{r}0.2680 \\
(5.97)\end{array}$ & $\begin{array}{r}0.1579 \\
(2.96)\end{array}$ & $\begin{array}{l}1.3647 \\
(33.20)\end{array}$ & $\begin{array}{l}1.2234 \\
(39.34)\end{array}$ & $\begin{array}{l}1.1108 \\
(28.86)\end{array}$ & $\begin{array}{l}0.9746 \\
(29.91)\end{array}$ & $\begin{array}{r}0.2612 \\
(6.33)\end{array}$ & $\begin{array}{r}0.1955 \\
(4.12)\end{array}$ \\
\hline$s$ & & $\begin{array}{l}0.9638 \\
(14.94)\end{array}$ & & $\begin{array}{c}0.7626 \\
(11.46)\end{array}$ & & $\begin{array}{r}0.1328 \\
(1.73)\end{array}$ & & $\begin{array}{l}0.9585 \\
(25.01)\end{array}$ & & $\begin{array}{l}0.8347 \\
(16.10)\end{array}$ & & $\begin{array}{r}0.0667 \\
(0.85)\end{array}$ & & $\begin{array}{c}1.0089 \\
(19.30)\end{array}$ & & $\begin{array}{c}0.7669 \\
(16.85)\end{array}$ & & $\begin{array}{r}0.1821 \\
(2.56)\end{array}$ \\
\hline$h$ & & $\begin{array}{c}-0.0862 \\
(-1.81)\end{array}$ & & $\begin{array}{c}0.0186 \\
(0.34)\end{array}$ & & $\begin{array}{c}-0.3464 \\
(-4.37)\end{array}$ & & $\begin{array}{r}-0.1481 \\
(-3.13)\end{array}$ & & $\begin{array}{r}0.1778 \\
(2.89)\end{array}$ & & $\begin{array}{r}-0.4090 \\
(-4.94)\end{array}$ & & $\begin{array}{c}-0.0879 \\
(-1.88)\end{array}$ & & $\begin{array}{r}0.0274 \\
(0.47)\end{array}$ & & $\begin{array}{r}-0.2614 \\
(-3.23)\end{array}$ \\
\hline$\delta$ & $\begin{array}{r}0.0163 \\
(0.06)\end{array}$ & $\begin{array}{r}0.0279 \\
(0.21)\end{array}$ & $\begin{array}{r}-0.1290 \\
(-0.93)\end{array}$ & $\begin{array}{r}0.2298 \\
(1.73)\end{array}$ & $\begin{array}{c}-0.1674 \\
(-0.85)\end{array}$ & $\begin{array}{r}-0.1858 \\
(-0.95)\end{array}$ & $\begin{array}{c}-0.0230 \\
(-0.07)\end{array}$ & $\begin{array}{r}-0.0412 \\
(-0.19)\end{array}$ & $\begin{array}{c}-0.2334 \\
(-1.52)\end{array}$ & $\begin{array}{r}0.0194 \\
(0.13)\end{array}$ & $\begin{array}{c}-0.0212 \\
(-0.11)\end{array}$ & $\begin{array}{c}-0.0278 \\
(-0.14)\end{array}$ & $\begin{array}{r}-0.1309 \\
(-0.35)\end{array}$ & $\begin{array}{r}-0.0068 \\
(-0.04)\end{array}$ & $\begin{array}{r}-0.2326 \\
(-1.34)\end{array}$ & $\begin{array}{r}0.0088 \\
(0.06)\end{array}$ & $\begin{array}{r}0.0927 \\
(0.41)\end{array}$ & $\begin{array}{r}0.1235 \\
(0.54)\end{array}$ \\
\hline$\omega$ & $\begin{array}{r}0.0002 \\
(1.72)\end{array}$ & $\begin{array}{r}0.0001 \\
(2.62)\end{array}$ & $\begin{array}{r}0.0001 \\
(1.76)\end{array}$ & $\begin{array}{r}0.0001 \\
(2.28)\end{array}$ & $\begin{array}{r}0.0005 \\
(2.33)\end{array}$ & $\begin{array}{r}0.0005 \\
(2.50)\end{array}$ & $\begin{array}{r}0.0002 \\
(1.58)\end{array}$ & $\begin{array}{r}0.0001 \\
(3.16)\end{array}$ & $\begin{array}{r}0.0001 \\
(1.60)\end{array}$ & $\begin{array}{c}0.0001 \\
(2.25)\end{array}$ & $\begin{array}{r}0.0002 \\
(1.81)\end{array}$ & $\begin{array}{r}0.0003 \\
(1.92)\end{array}$ & $\begin{array}{r}0.0002 \\
(1.53)\end{array}$ & $\begin{array}{r}0.0001 \\
(4.04)\end{array}$ & $\begin{array}{r}0.0000 \\
(1.67)\end{array}$ & $\begin{array}{c}0.0001 \\
(1.56)\end{array}$ & $\begin{array}{c}0.0001 \\
(1.41)\end{array}$ & $\begin{array}{r}0.0001 \\
(1.34)\end{array}$ \\
\hline$\gamma$ & $\begin{array}{c}0.1941 \\
(2.47)\end{array}$ & $\begin{array}{r}0.6725 \\
(1.48)\end{array}$ & $\begin{array}{r}0.0019 \\
(0.07)\end{array}$ & $\begin{array}{r}0.0140 \\
(0.43)\end{array}$ & $\begin{array}{c}0.5729 \\
(2.71)\end{array}$ & $\begin{array}{r}0.6220 \\
(2.89)\end{array}$ & $\begin{array}{r}0.1834 \\
(2.47)\end{array}$ & $\begin{array}{r}0.4409 \\
(6.34)\end{array}$ & $\begin{array}{r}0.0079 \\
(0.32)\end{array}$ & $\begin{array}{c}0.0238 \\
(0.65)\end{array}$ & $\begin{array}{r}0.3752 \\
(2.62)\end{array}$ & $\begin{array}{r}0.4545 \\
(2.45)\end{array}$ & $\begin{array}{c}0.1460 \\
(2.18)\end{array}$ & $\begin{array}{r}0.6199 \\
(1.00)\end{array}$ & $\begin{array}{r}0.0106 \\
(0.67)\end{array}$ & $\begin{array}{r}0.0516 \\
(1.43)\end{array}$ & $\begin{array}{r}0.2348 \\
(2.10)\end{array}$ & $\begin{array}{r}0.1657 \\
(2.07)\end{array}$ \\
\hline$\eta$ & $\begin{array}{c}-0.2081 \\
(-2.56)\end{array}$ & $\begin{array}{c}-0.5849 \\
(-1.33)\end{array}$ & $\begin{array}{r}0.3501 \\
(3.07)\end{array}$ & $\begin{array}{r}0.4977 \\
(3.24)\end{array}$ & $\begin{array}{c}-0.5216 \\
(-2.48)\end{array}$ & $\begin{array}{c}-0.5511 \\
(-2.56)\end{array}$ & $\begin{array}{c}-0.1670 \\
(-2.25)\end{array}$ & $\begin{array}{r}-0.2973 \\
(-2.41)\end{array}$ & $\begin{array}{r}0.2808 \\
(2.59)\end{array}$ & $\begin{array}{r}0.6291 \\
(3.42)\end{array}$ & $\begin{array}{c}-0.3580 \\
(-2.52)\end{array}$ & $\begin{array}{c}-0.4207 \\
(-2.28)\end{array}$ & $\begin{array}{r}-0.0788 \\
(-0.97)\end{array}$ & $\begin{array}{r}-0.1905 \\
(-0.36)\end{array}$ & $\begin{array}{r}0.1391 \\
(2.83)\end{array}$ & $\begin{array}{r}0.4295 \\
(3.56)\end{array}$ & $\begin{array}{c}-0.2212 \\
(-2.01)\end{array}$ & $\begin{array}{r}-0.1517 \\
(-1.92)\end{array}$ \\
\hline$\theta$ & $\begin{array}{r}0.7963 \\
(8.57)\end{array}$ & $\begin{array}{r}0.6000 \\
(5.56)\end{array}$ & $\begin{array}{c}0.8042 \\
(29.48)\end{array}$ & $\begin{array}{c}0.7242 \\
(10.40)\end{array}$ & $\begin{array}{r}0.6004 \\
(5.43)\end{array}$ & $\begin{array}{r}0.5592 \\
(5.01)\end{array}$ & $\begin{array}{c}0.7861 \\
(7.91)\end{array}$ & $\begin{array}{r}0.6202 \\
(8.71)\end{array}$ & $\begin{array}{c}0.8484 \\
(15.79)\end{array}$ & $\begin{array}{l}0.6555 \\
(10.32)\end{array}$ & $\begin{array}{l}0.7677 \\
(10.43)\end{array}$ & $\begin{array}{r}0.6812 \\
(6.56)\end{array}$ & $\begin{array}{r}0.7352 \\
(5.32)\end{array}$ & $\begin{array}{r}0.3625 \\
(2.40)\end{array}$ & $\begin{array}{l}0.9095 \\
(29.04)\end{array}$ & $\begin{array}{r}0.7200 \\
(9.22)\end{array}$ & $\begin{array}{l}0.8353 \\
(11.20)\end{array}$ & $\begin{array}{c}0.8717 \\
(14.78)\end{array}$ \\
\hline$\gamma+\eta / 2+\theta$ & 0.8864 & 0.9800 & 0.9811 & 0.9870 & 0.9125 & 0.9056 & 0.8860 & 0.9125 & 0.9967 & 0.9938 & 0.9638 & 0.9254 & 0.8417 & 0.8871 & 0.9897 & 0.9864 & 0.9595 & 0.9616 \\
\hline
\end{tabular}

